\title{
Comparative Carcinogenicity in Sprague-Dawley Rats of the Polychlorinated Biphenyl Mixtures Aroclors 1016, 1242, 1254, and 1260
}

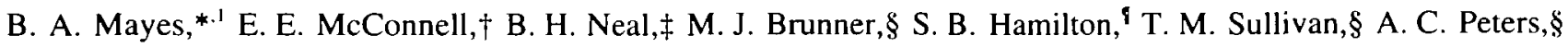

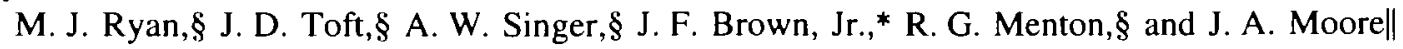 \\ *General Electric Corporate Research \& Development, Schenectady, New York; †ToxPath, Inc., Raleigh, North Carolina; \\ $\ddagger$ Jellinek, Schwartz \& Connolly, Inc., Arlington, Virgınıa; \$Battelle Laboratories, Columbus, Ohio; \\ ${ }^{1}$ General Electric Co., Fairfield, Connectucut; and \|Institute for Evaluating Health Risks, Washington, DC
}

Received August 28, 1997; accepted October 22, 1997

Comparative Carcinogenicity in Sprague-Dawley Rats of the Polychlorinated Biphenyl Mixtures Aroclors 1016, 1242, 1254, and 1260. Mayes, B. A., McConnell, E. E., Neal, B. H., Brunner, M. J., Hamilton, S. B., Sullivan, T. M., Peters, A. C., Ryan, M. J., Toft, J. D., Singer, A. W., Brown, J. F., Jr., Menton, R. G., and Moore, J. A. (1998). Toxicol. Sci. 41, 62-76.

A comprehensive chronic toxicity and carcinogenicity study was conducted on a series of Aroclors (1016, 1242, 1254, and 1260). Each Aroclor was assessed at multiple dietary concentrations, ranging from 25 to $200 \mathrm{ppm}$, for 24 months in male and female Sprague-Dawley rats. Liver toxicity was indicated by elevated serum enzyme activity (AST, ALT, and GGT), elevated serum cholesterol concentration, decreases in hematologic parameters ( $\mathrm{RBC}, \mathrm{Hb}$, and $\mathrm{Hct}$ ), hepatocellular hypertrophy, an increased incidence of altered hepatocellular foci, and an increased incidence of hepatocellular neoplasms (primarily adenomas). Liver toxicity was distinctly more severe in females than in males. The incidence of hepatocellular neoplasms was highly sex-dependent (females $\rightarrow$ males), differed between Aroclor mixtures and, for females, increased with dose and followed the general incidence pattern of Aroclor $1254>$ Aroclor $1260 \approx$ Aroclor $1242>$ Aroclor 1016. A significant response $(p<0.05)$ in males was seen only for the high dose of Aroclor 1260. A small increase in the incidence of thyroid gland follicular cell adenomas was noted in males for Aroclors 1242,1254 , and 1260 , with the incidence being uniform across dose groups and Aroclor mixtures. For females, increased survival relative to controls was observed for all Aroclor treatment groups. A significantly decreased trend in the incidence of mammary gland neoplasms compared to control was also noted for females receiving Aroclors 1242, 1254, and 1260. 1998 Sociey of Toxicotogy.

Key Words: PCB; polychlorinated biphenyls; Aroclor; Aroclor 1016; Aroclor 1242; Aroclor 1254; Aroclor 1260; cancer; carcinogenicity; rat; Sprague-Dawley; mammary tumors; liver tumors; thyroid tumors; sex difference; risk assessment.

\footnotetext{
' To whom correspondence should be addressed at GE Corp. Res. \& Development. P.O. Box 8, 1 River Rd.. Schenectady, NY 12301. Fax: (518) 387-7611.
}

Aroclors 1016, 1242, 1254, and 1260 are complex mixtures of polychlorinated biphenyl (PCB) congeners, prepared by the chlorination of biphenyl. For Aroclors 1242, 1254, and 1260 , the chlorination reaction was stopped when the weight percent chlorine of the product had reached 42, 54, or $60 \%$, respectively. By contrast, Aroclor 1016 was prepared by the fractional distillation of Aroclor 1242, which excluded the higher boiling (i.e., more highly chlorinated) congeners. Aroclors 1016, 1242, 1254, and 1260 were the most widely used PCBs in the United States, and accounted for 92\% of all 1958-1977 production (Monsanto, 1980). Polychlorinated biphenyls were versatile materials which found use in a variety of applications including plasticizers, printing inks, and heat exchange, dielectric, and hydraulic fluids. The dielectric properties, chemical stability, and noncombustibility of PCB fluids made them a particularly attractive alternative to flammable mineral oils for use in capacitors and indoor transformers.

Concerns in the late-1960s regarding the environmental accumulation of highly chlorinated PCB mixtures resulted, in 1971, in a voluntary cessation of the manufacture of Aroclors 1232, 1248, 1260,1262, and 1268; the introduction of Aroclor 1016; and to a restriction in PCB usage to totally enclosed systems. The Toxic Substances Control Act of 1976 made the manufacture, importation, sale, or use of PCBs illegal after 1978.

The tumorigenicity of PCBs in rodents was first reported in mice by Nagasake et al. (1972) and Ito et al. (1973), which were followed by reports of tumorigenicity in rats by Kimbrough et al. (1975), Schaeffer et al. (1984), Norback and Weltman (1985), and the National Cancer Institute (NCI) (1978). In many instances, study features such as single sex representation, single exposure concentration, and restriction of evaluation to only highly chlorinated mixtures (mainly $60 \% \mathrm{Cl}$ compositions) severely limited the interpretative value of the data set. The studies in rats formed the basis for the Environmental Protection Agency 
TABLE 1

Comparison of Composition of Aroclor Mixtures Tested

\begin{tabular}{|c|c|c|c|c|c|}
\hline \% 1958-77 U S. Production & 12.88 & 51.76 & $\geq 15.2^{\circ}$ & $\leq 0.5^{b}$ & 10.61 \\
\hline Lot No. & 129 & 01141 & & $122-078$ & $021-020$ \\
\hline Monochloro-BPs & 0.83 & 0.08 & 0.00 & 0.00 & 0.00 \\
\hline Tetrachloro-BPs & 25.84 & 33.49 & 20.62 & 19.67 & 2.41 \\
\hline Pentachloro-BPs & 0.69 & 6.64 & 43.68 & 45.33 & 11.96 \\
\hline Hexachloro-BPs & 0.01 & 1.70 & 29.22 & 31.38 & 39.28 \\
\hline Heptachloro-BPs & 0.00 & 0.10 & 3.78 & 2.76 & 36.38 \\
\hline Octachloro-BPs & 0.00 & 0.01 & 0.11 & 0.07 & 7.67 \\
\hline Nonachloro-BPs & 0.00 & 0.00 & 0.00 & 0.02 & 1.59 \\
\hline Total Cl/BP & 3.02 & 3.27 & 5.03 & 5.10 & 6.29 \\
\hline$\$ P C B s>C l / B P$ & 0.70 & 8.45 & 76.79 & 79.56 & 96.95 \\
\hline \multicolumn{6}{|l|}{ Select coplanar concentrations (ppm) } \\
\hline PCDD (total) & 0.0 & 0.0 & 0.02 & 0.0 & 0.0 \\
\hline PCDF (total) & 0.05 & 22 & 1.0 & 0.13 & 5.5 \\
\hline PCB $77\left(3,3^{\prime}, 4,4^{\prime}-\mathrm{PCB}\right)$ & 52.0 & 3130 & 266 & 1034 & 29.7 \\
\hline PCB $126\left(3,3^{\prime}, 4,4^{\prime}, 5\right.$-PCB $)$ & 0.72 & 41 & 44 & 146 & ND \\
\hline PCB $169\left(3,3^{\prime}, 4,4^{\prime}, 5,5^{\prime}-\mathrm{PCB}\right)$ & ND & ND & ND & ND & ND \\
\hline \multicolumn{6}{|l|}{ TEQ contributions (ppm) } \\
\hline TEQ (PCDD/F) & 0.002 & 0.1 & 0.07 & 0.01 & 0.08 \\
\hline TEQ (PCB) & 0.11 & 7.7 & 23.3 & 47.6 & 7.1 \\
\hline TEQ (Total) & 0.11 & 7.8 & 23.4 & 47.6 & 7.2 \\
\hline TEQ (Total less PCB 77) & 0.08 & 6.2 & 23.3 & 47.1 & 7.2 \\
\hline
\end{tabular}

Note. Abbreviations used: Biphenyl, BP; polychlorinated dibenzodioxin, PCDD; polychlorinated dibenzofuran, PCDF; polychlorinated biphenyl, PCB; toxic equivalency, TEQ.

a This composition represents the mixture of Aroclor 1254 that was most extensively used commercially (1958-1977) and is included in the table for companson.

${ }^{b}$ The lot of Aroclor 1254 available for preparing the test article (Monsanto No. KI-02-6024) was produced in 1976 using a modified procedure that was in use ca. 1976-1977. Prior to administenng Aroclor 1254 in the current study, it was treated by AccuStandard using Preston's procedure (Preston et al., 1981) (producing Lot No. 122-078) which removed $>99 \%$ of the PCDFs and about 35\% of congener 126 originally present in Lot KI-02-6024.

c ND, none detected.

(EPA) classification of PCBs as probable (Group B2) carcinogens (U.S. Environmental Protection Agency, 1988). In studies where PCB mixtures of differing chlorine content have been evaluated (Ito et al., 1973; Nagasaki et al., 1972; Schaeffer et al., 1984), the data suggest that tumorigenic potential decreases with decreasing chlorination; nevertheless, the EPA chose to regulate all PCBs as equivalent to highly chlorinated mixtures, with a cancer potency factor of $7.7\left(\mathrm{mg} / \mathrm{kg} \cdot\right.$ day) ${ }^{-1}$ (U.S. Environmental Protection Agency, 1988).

In 1993, the General Electric Co. initiated a 2-year carcinogenicity study in Sprague-Dawley rats which conformed to EPA testing (U.S. Environmental Protection Agency,
1992) and Good Laboratory Practice (U.S. Environmental Protection Agency, 1992) guidelines. The purpose of this study was to allow direct comparisons of the most widely used Aroclors (1016, 1242, 1254, and 1260) in a design that would facilitate evaluation for dose response, chronic toxicity, carcinogenicity, neurotoxicity, and toxicokinetics. The current paper reports the findings associated with the carcinogenicity (24-month exposure) segment of this study.

\section{MATERIALS AND METHODS}

Animals. Six hundred fifty male and 650 female Sprague-Dawley rats (Charles River Laboratories, Portage, MI), 6-7 (males) or 7-8 (females) 


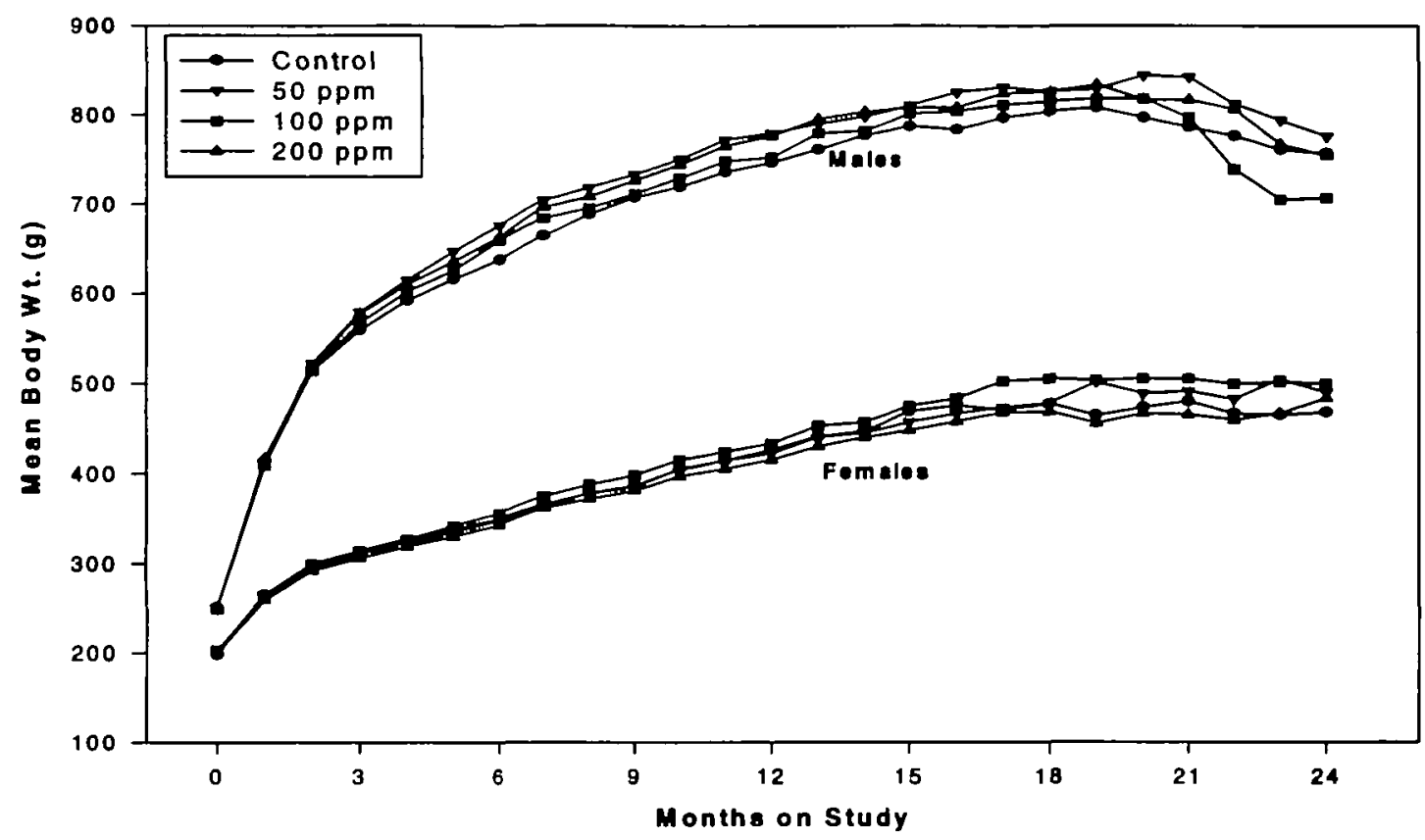

FIG. 1. Group mean body weights for Aroclor 1016.

weeks old, and weighing 248-252 g (males) and 198-203 g (females), respectively, at study initiation, were assigned to 11 treatment groups (50 rats/sex/dose group) and one control group (100 rats/sex) in a manner that minimized group mean body weight differences. These groups were augmented by additional animals for evaluations of chronic toxicity and neurotoxicity and the progression and reversibility of pathology, the results of which will be reported separately.

Prior to study initiation, anımals were certified free of Sendai vırus, pneumonia virus of mice, coronavirus/sialodacryoadentis, Kilham rat virus, Toolan's H-l virus, and Mycoplasma pulmonis by collecting serum from 5 rats/sex for evaluation (Microbiological Associates, Inc., Rockville, MD). All animals were acclimated to, and maintained in, a controlled environment of $68-80^{\circ} \mathrm{F}, 40-70 \%$ relative humidity and $12-\mathrm{h}$ light/dark cycles. Animals were identified by tail tattoos and individually housed in stainless-steel wire mesh cages. Twice each day animals were evaluated for clinical signs and mortality. Once per month for the first 6 months, and weekly thereafter,

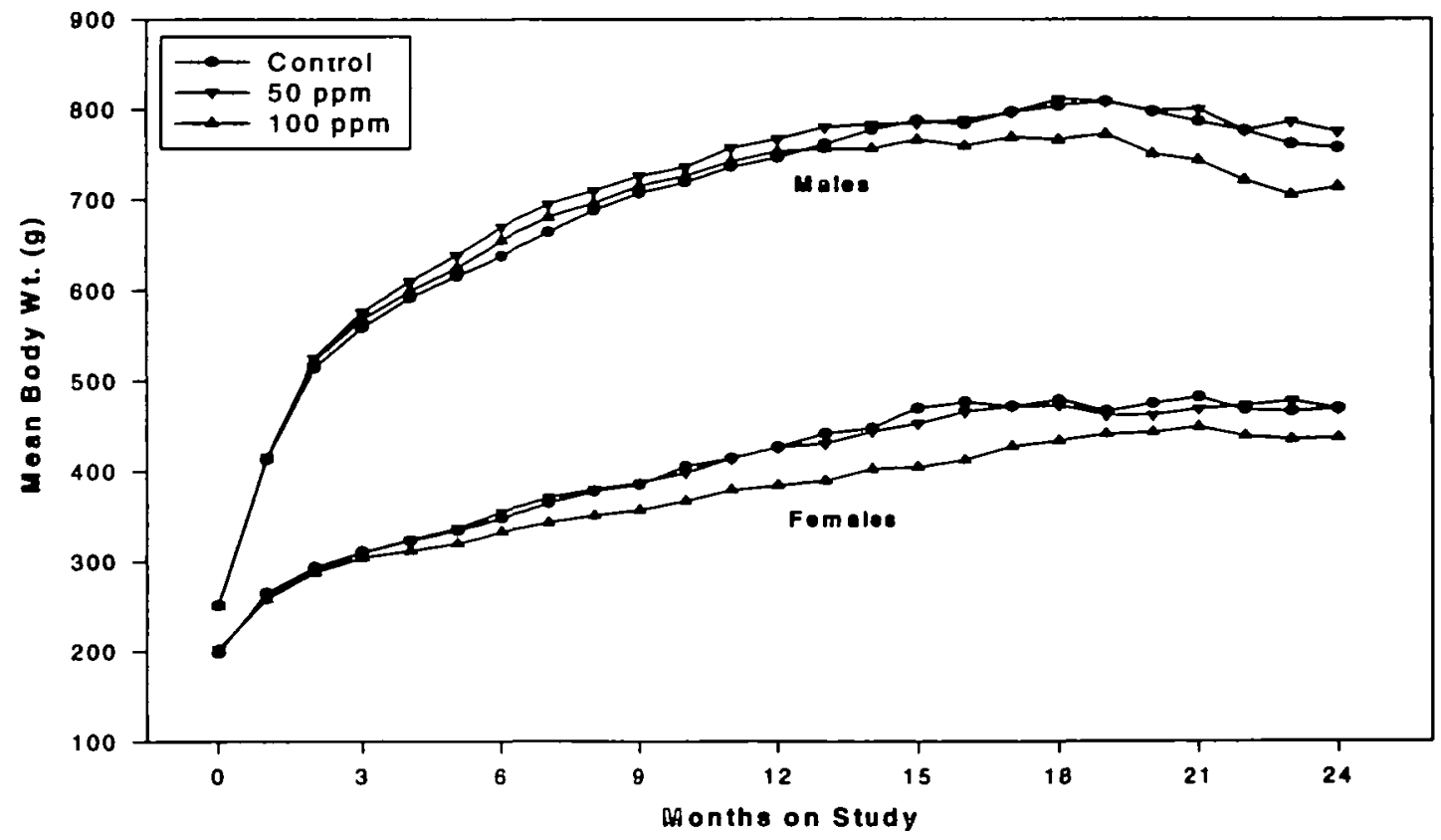

FIG. 2. Group mean body weights for Aroclor 1242. 


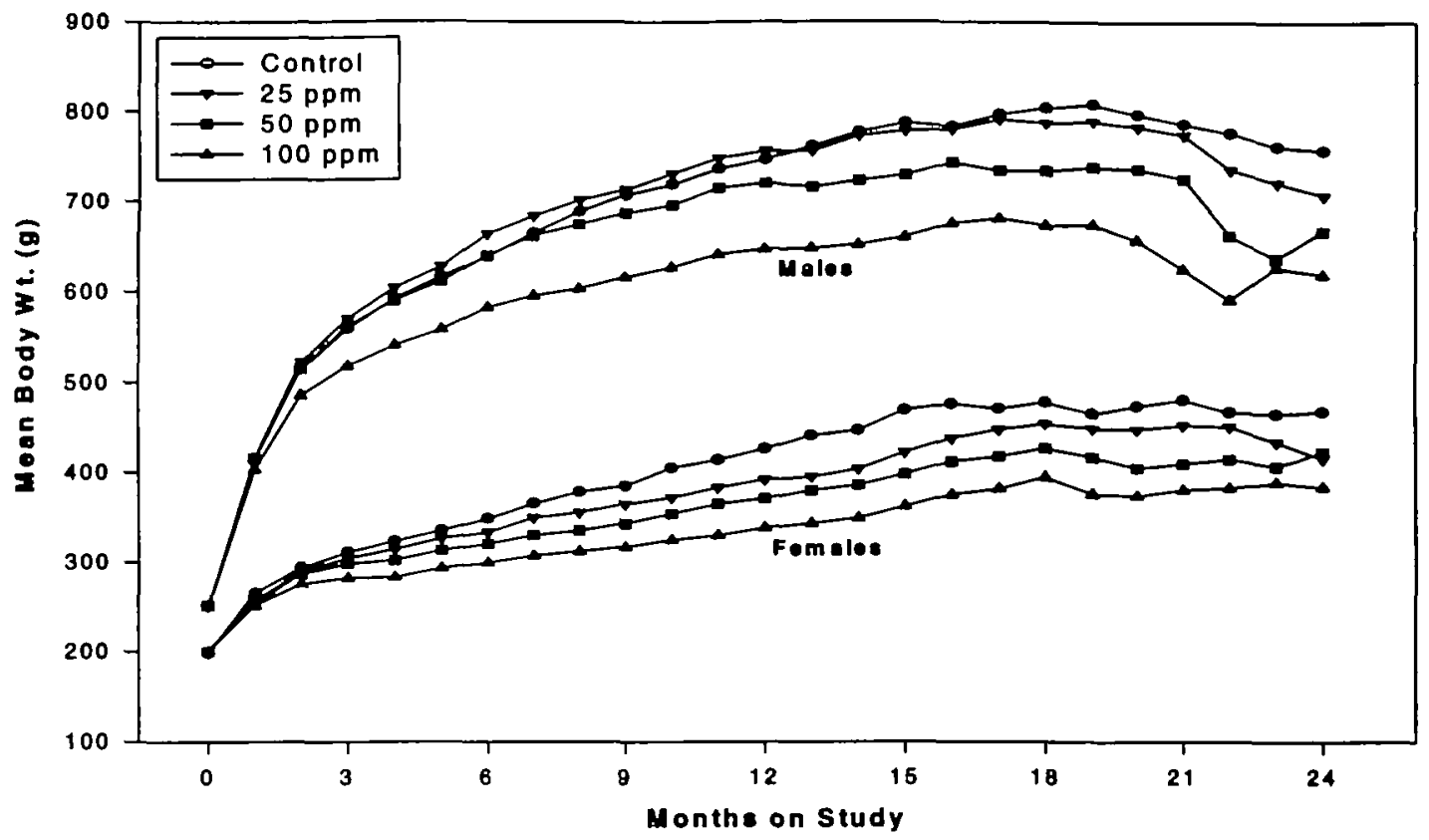

FIG. 3. Group mean body weights for Aroclor 1254

animals were examıned in detail by palpation for tissue masses or other abnormalities. Ophthalmic examinations were conducted on all animals prior to study inituation and on all surviving control and high-dose group anımals from each Aroclor at 24 months.

All groups assigned to a single Aroclor mixture were segregated in compound-specific animal treatment rooms. The controls were housed sepa- rately. To minumze the potential for cross-contamination, technical staff members either were restricted to working with a single Aroclor mixture or were required to shower and regarment before entering a different Aroclor animal treatment room. Animal housing and care conformed with the guidelines established by the NIH Guide for the Care and Use of Laboratory Animals, NIH Publication No. 86-23.

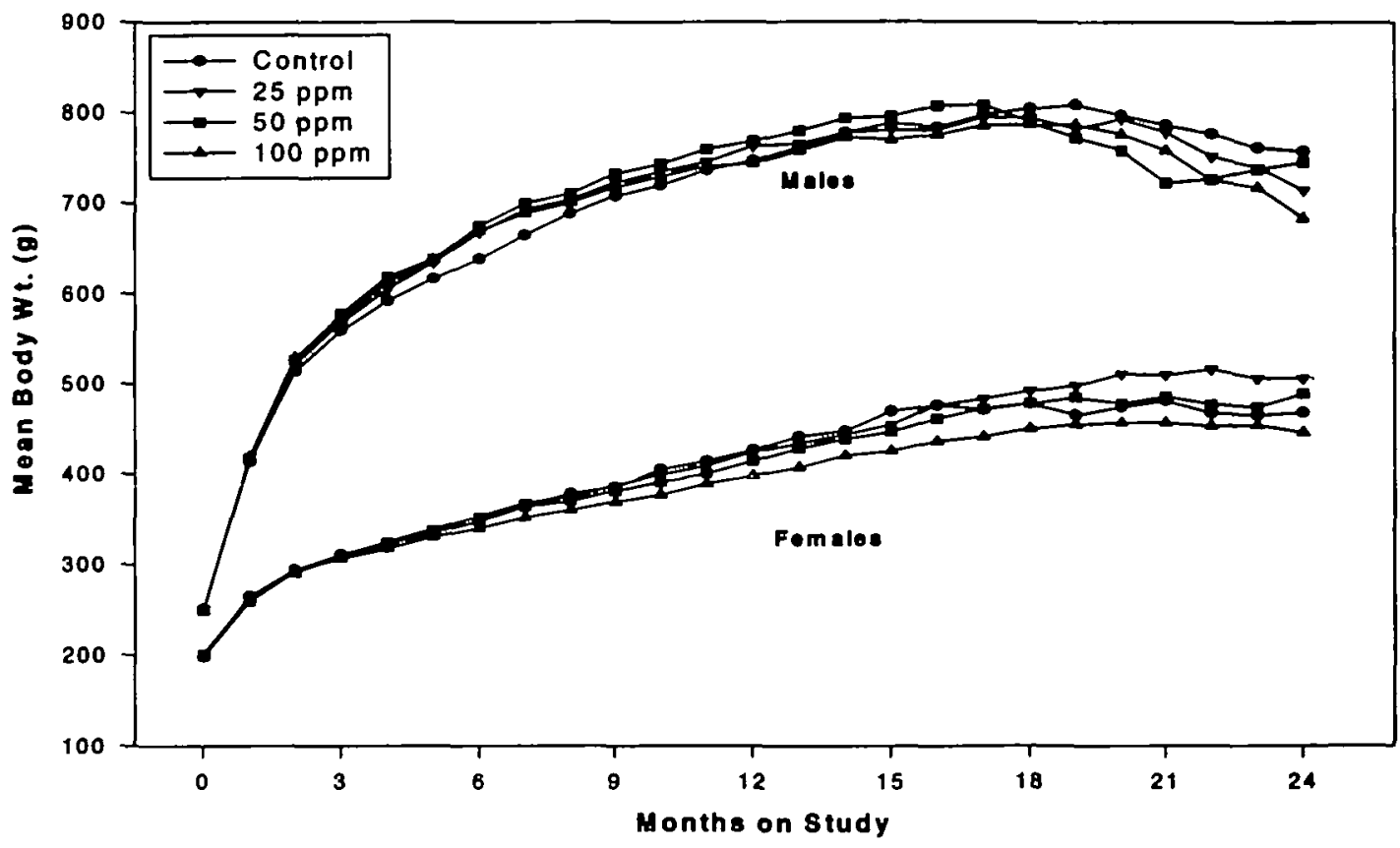

FIG. 4. Group mean body weights for Aroclor 1260. 
TABLE 2

Mean Daily Dietary PCB Consumption

\begin{tabular}{lllc}
\hline & & \multicolumn{2}{c}{$\begin{array}{c}\text { PCB consumption } \\
\text { (mg/kg/day) }\end{array}$} \\
\cline { 3 - 4 } Group & $\begin{array}{c}\text { Dose } \\
\text { (ppm) }\end{array}$ & \multicolumn{1}{c}{ Males } & Females \\
\hline Control & 0 & 0 & 0 \\
Aroclor 1016 & 50 & $2.0(1.5-4.4)$ & $2.7(1.9-4.3)$ \\
& 100 & $4.0(3.0-8.8)$ & $5.4(4.2-8.8)$ \\
Aroclor 1242 & 200 & $8.0(6.4-17.4)$ & $11.2(9.0-19.0)$ \\
Aroclor 1254 & 50 & $2.0(1.6-4.3)$ & $2.8(21-4.7)$ \\
& 100 & $4.0(3.2-8.7)$ & $5.7(4.4-9.0)$ \\
& 25 & $1.0(0.8-2.2)$ & $1.4(1.1-2.2)$ \\
Aroclor 1260 & 50 & $2.0(1.6-4.3)$ & $2.9(2.3-4.5)$ \\
& 100 & $4.3(3.5-8.3)$ & $6.1(5.1-9.0)$ \\
& 25 & $1.0(0.9-2.2)$ & $1.4(1.0-2.3)$ \\
& 50 & $2.0(1.6-4.3)$ & $2.8(2.2-4.8)$ \\
& 100 & $4.1(3.3-8.5)$ & $5.8(4.5-9.3)$ \\
\hline
\end{tabular}

a Mean (group mean lifetıme range)

Test materials and diet. Aroclor $1016(41 \% \mathrm{Cl}$, Lot 129), Aroclor 1242 (42\% Cl, Lot 01141), Aroclor 1254 (54\% Cl, Lot 122-078), and Aroclor $1260(60 \% \mathrm{Cl}$, Lot 021-020) were obtained from AccuStandard, Inc. (New Haven, CT). All four test substances were evaluated prior to study initiation for concentrations of polychlorinated dibenzodioxin (PCDD) and polychlo-

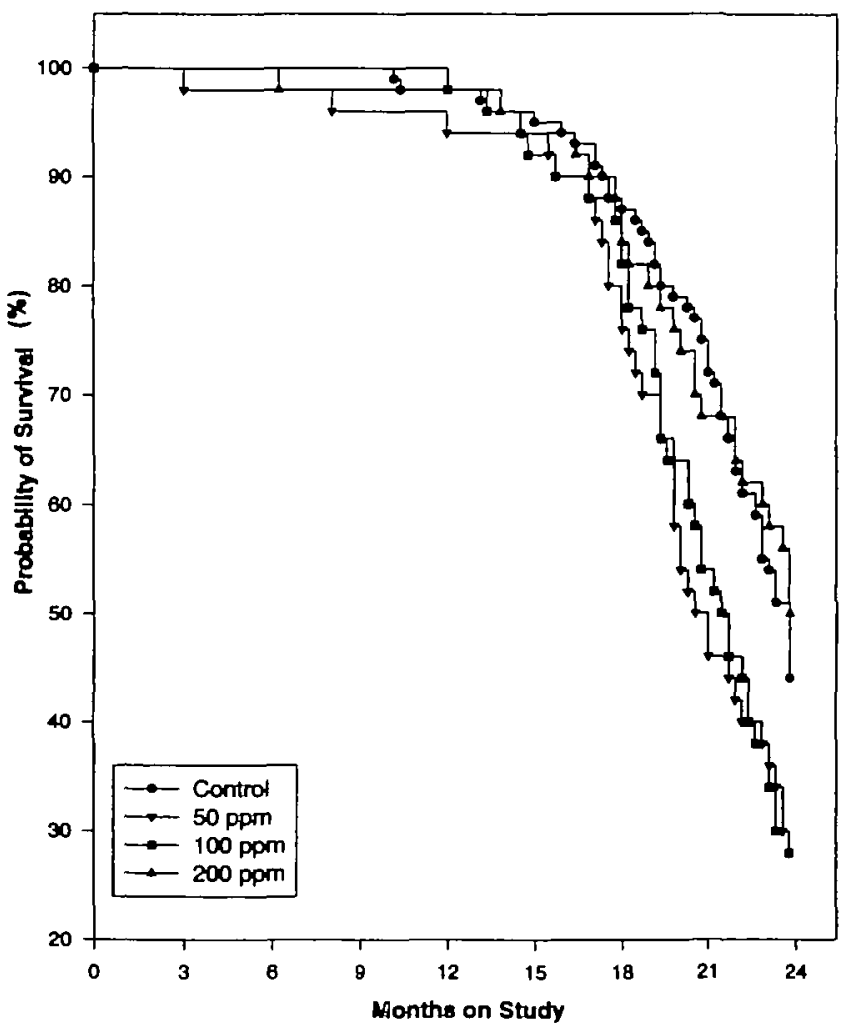

FIG. 5. Kaplan-Meier survival curves: Aroclor 1016 males.

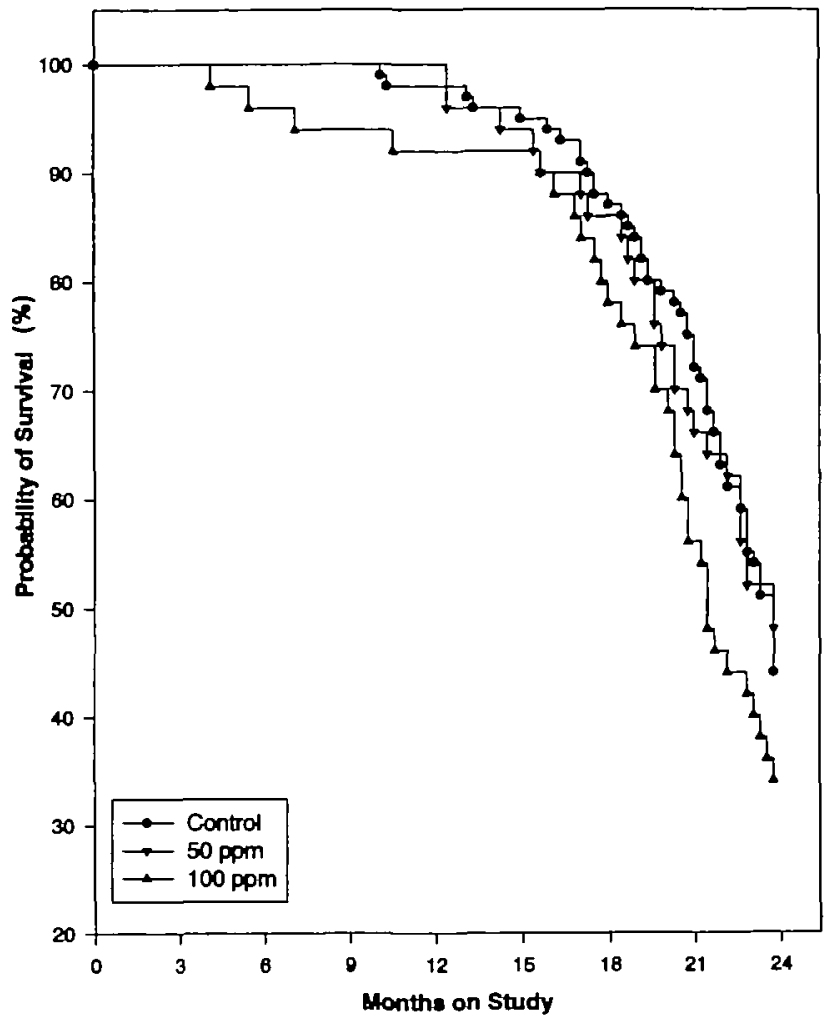

FIG. 6. Kaplan-Meier survival curves: Aroclor 1242 males.

nnated dibenzofuran (PCDF) by Twin City Testing, Co. (now Maxim Technologies, Inc.) (St. Paul, MN) (Table 1). PCDD concentrations were 0.6, 0,20 , and $0 \mathrm{ppb}$ for Aroclors 1016, 1242,1254, and 1260, respectively PCDF analyses showed total concentrations to be within acceptable ranges for Aroclors 1016, 1242, and 1260 (i.e., 0.035, 29 , and 4.9 ppm, respectively), but elevated for Aroclor 1254 (23 ppm). Accordingly, Aroclor 1254 was treated for PCDF removal by AccuStandard using the procedure of Preston et al. (1981). This removed $>99 \%$ of the PCDFs and also reduced the concentration of congener $126\left(3,3^{\prime}, 4,4^{\prime}, 5-\mathrm{PCB}\right)$ approxımately $35 \%$, but still left the concentration of congener 126 three to five times greater, and consequently the TEQ (toxic equivalency) about two times greater (calculated as per Ahlborg (1994)), than that of ordinary Aroclor 1254. It was subsequently found that this lot of Aroclor 1254 had been made by a modified procedure that was used only in the final years of manufacture, and accounted for under $1 \%$ of the total Aroclor 1254 production for the years 1958-1977.

All test materials were administered in the feed (Purina Rodent Chow Meal No. 5002) fed ad libitum. Each lot of the basal diet was confirmed by the manufacturer to contain $<0.15 \mathrm{ppm}$ of PCB. Dosed diets were prepared by dissolving Aroclor in hexane and combining with a small amount of diet (the "premıx"). The hexane was evaporated, and the premix was subsequently blended (Patterson-Kelley Cross Flow Blender) with an appropriate amount of basal diet to achieve the desired final PCB concentrations. Control feed was handled in a similar manner, without the addition of test material. Periodically dunng the study, samples were taken to confirm that diet preparations were achieving target PCB concentrations, were homogenous, and were not cross-contaminated. Randomly selected samples of diet were also periodically submitted to an independent laboratory (Northeast Analytical Laboratories, Schenectady. NY) for referee PCB concentration analyses. 
Feed consumption was monitored "continuously" throughout the study by determining the quantuty of feed consumed at weekly intervals. Water was supplied ad libitum from a municipal water supply and was analyzed periodically for microbes and other contaminants, including PCBs.

In addition to evaluations for mortality, clinical signs, and palpation for tissue masses described previously, general toxicity was monitored using weekly body weight and feed consumption data.

Serum chemistries, hematology, and urinalyses. At 24 months, urine was collected from 10 nonfasted animals/sex/group over a period of approximately $18 \mathrm{~h}$ for measurement and evaluation of specific gravity, volume, color, appearance, and microscopic charactenstics; and qualitauve dipstick determination (Rapignost, Behringwerk AG, Marburg, Germany) of $\mathrm{pH}$, protein, glucose, blood, ketones, bilirubin, and urobilinogen. Subsequently, these animals were anesthetized by $\mathrm{CO}_{2}$ inhalation and blood was collected from the retro-orbital sinus. Serum chemistry evaluations included aspartate aminotransferase (AST), alanine aminotransferase (ALT), alkaline phosphatase (ALP), $\gamma$-glutamyl transpeptidase (GGT), lactate dehydrogenase (LD), urea nitrogen (BUN), creatinine, creatine kinase (CK), total protein, albumın, sodium, potassium, chloride, calcium, inorganıc phosphate, total bilirubin, cholesterol, and glucose. Hematology evaluations included red blood cell count (RBC), white blood cell count (WBC), differential count, platelet count, hematocrit $(\mathrm{Hct})$, hemoglobın concentration $(\mathrm{Hb})$, mean cell hemoglobin $(\mathrm{MCH})$, mean cell volume (MCV), and mean cell hemoglobın concentration (MCHC).

Pathology. At the end of the study (24 months), the surviving rats were kılled by $\mathrm{CO}_{2}$ asphyxiation and examıned for macroscopic lesions. Selected organs were removed and weighed. Tissue samples were fixed in $10 \%$ neutral-buffered Formalın, except eyes and testes which were preserved in Bouin's solution. The following tissues were fixed (and weighed (*)): adrenals (*), aorta, bone marrow, brain (*), cecum, colon, duodenum, epididy-

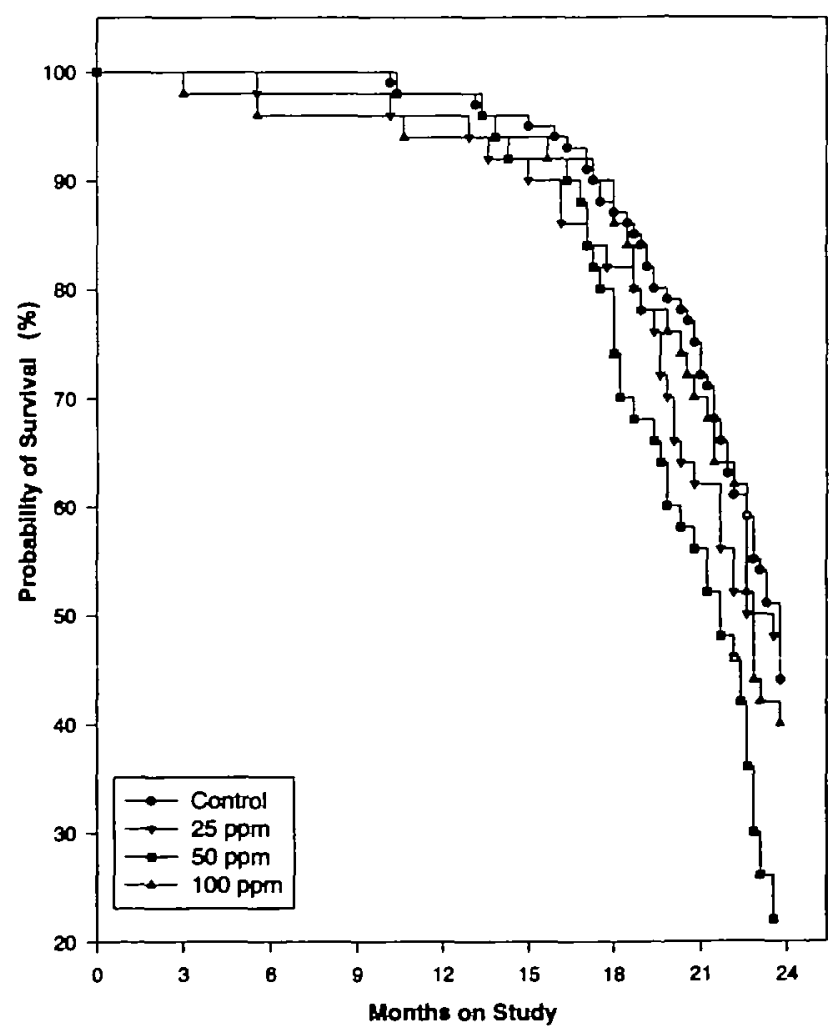

FIG. 7. Kaplan-Meier survival curves Aroclor 1254 males

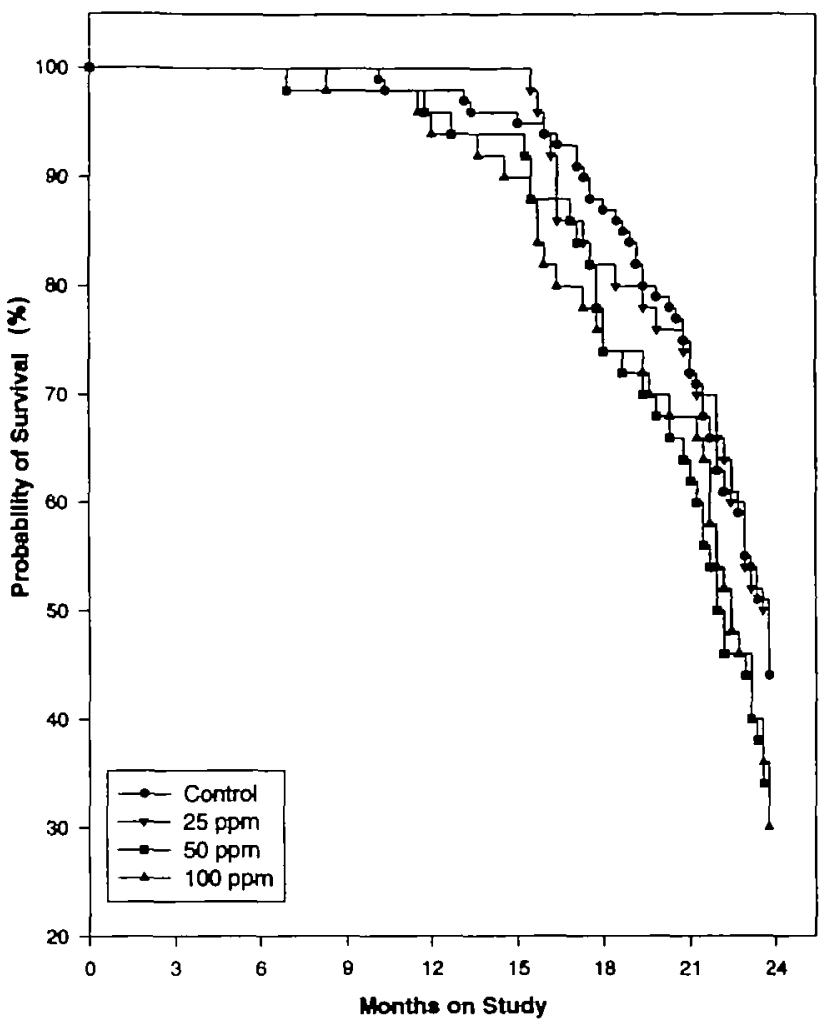

FIG. 8. Kaplan-Meier survival curves: Aroclor 1260 males.

mides (*), esophagus, eyes, femoris muscle, Harderian glands, heart (*), ıleum, jejunum, kidneys (*), exorbital lacrimal glands, liver (*), lungs (*), mammary gland, mesenteric lymph nodes, optic nerves, ovaries (*), pancreas, parathyroids, pituitary $(*)$, prostate $(*)$, rectum, sciatic nerve, seminal vesıcles $(*)$, skın, sublıngual and submaxillary $(*)$ salivary glands, spınal cord, spleen (*), sternum, stomach, testes (*), thymus (*), tongue, thyroid (* with parathyroids), trachea, urinary bladder, uterus (*), vagina, and gross lesions and tissue masses. Histopathologic evaluations of paraffin-embedded and hematoxylin- and eosin-stained sections were performed on the above organs/tissues for all animals from Aroclor high-dose groups and controls, and on all anımals that died prior to 24 months. Evaluations for all remaining animals included the brain, liver, mammary gland, and gross lesions of both sexes, and the thyroid gland for males. Upon completion of the study, all liver (both sexes) and thyroid gland (males) suspect neoplastic lesions were reviewed by a group of independent pathologists (Pathology Working Group) (Hardisty et al., 1996) without knowledge of exposure groups, utilızing the diagnostic criteria for proliferative hepatocellular and thyroıd lesions in rats currently proposed by the Society of Toxicologic Pathologists (Botts et al., 1991; Goodman et al., 1994).

Statistics. The primary objective of the statistical analysis was to determine whether the administration of Aroclor test substances in diet resulted in increased tumor occurrence. The number of neoplasms in Aroclor-dosed groups were compared to those observed in the Control group using Fisher's exact test (Haseman, 1984). Tests for linear trend were also conducted for tumor response data. Nonneoplastic histomorphologic lesions were not analyzed for statistical differences. Additional analyses were conducted to determine the effects of each Aroclor test substance on mortality, body weight, body weight gains, feed consumption, clinical pathology, and organ weights.

Survıval analysis assessments utilized Tarone's test for linear trend and 
Cox's log rank test for pairwise comparisons. Kaplan-Meier survival probabilities were calculated for all groups. Other in-life parameters were assessed using either Dunnett's test or $t$ tests with adjustments for multiple comparisons, following a preliminary analysis to select the appropriate test procedure.

Study conduct. This study was performed at Battelle Laboratories (Columbus, $\mathrm{OH}$ ) as study No. SC920192. The study was conducted in complance with Good Laboratory Practice Guidelines, and animal housing and care conformed to the Guide for the Care and Use of Laboratory Animals, NIH Publication No. 86-23.

\section{RESULTS}

Body weight and feed consumption. Group mean body weights for males in all treatment groups of Aroclors 1016, 1242 , and 1260 were not statistically different from those of control (Figs. 1-4). Dose-related significant decreases in group mean body weights were recorded for males in the 50 and $100 \mathrm{ppm}$ exposure groups of Aroclor $1254 \mathrm{be}$ ginning at 12 and 1 months, respectively. The decreases from control at 24 months were approximately 12 and $18 \%$, respectively.

Group mean body weights for females in all treatment groups of Aroclors 1016 and 1260 were not statistically different from those of control. Dose-related significant decreases in group mean body weights were recorded for the $100 \mathrm{ppm}$ Aroclor 1242 group beginning at approximately

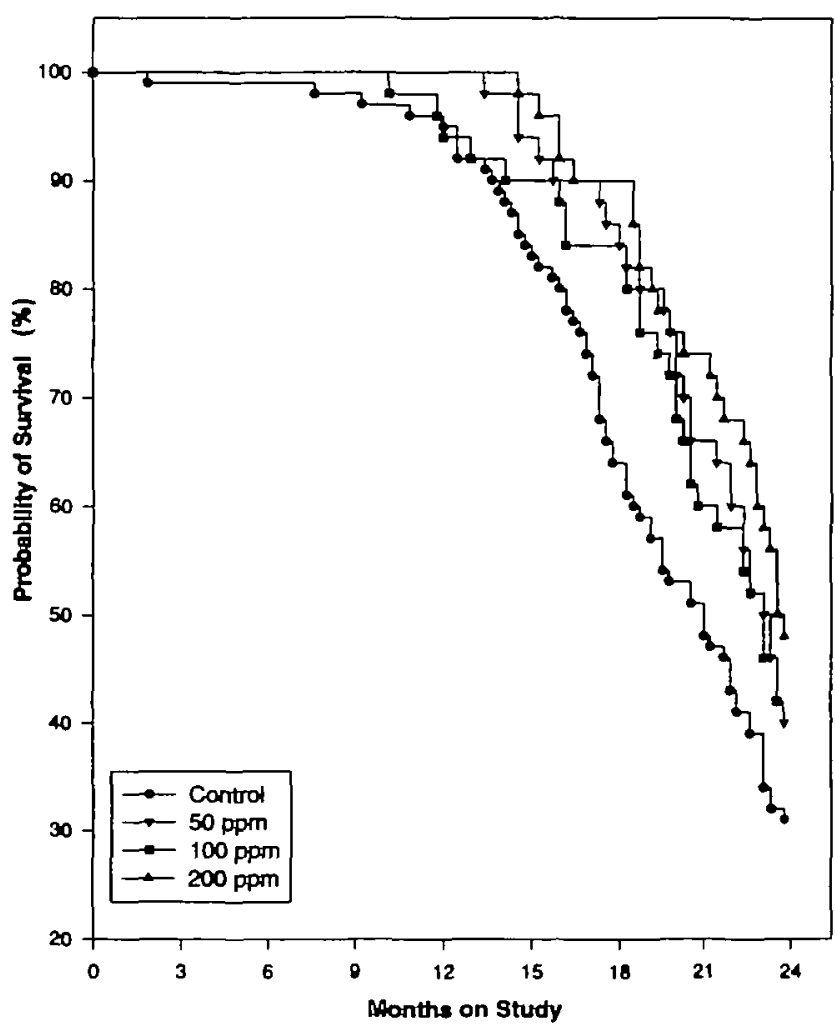

FIG. 9. Kaplan-Meier survival curves: Aroclor 1016 females.

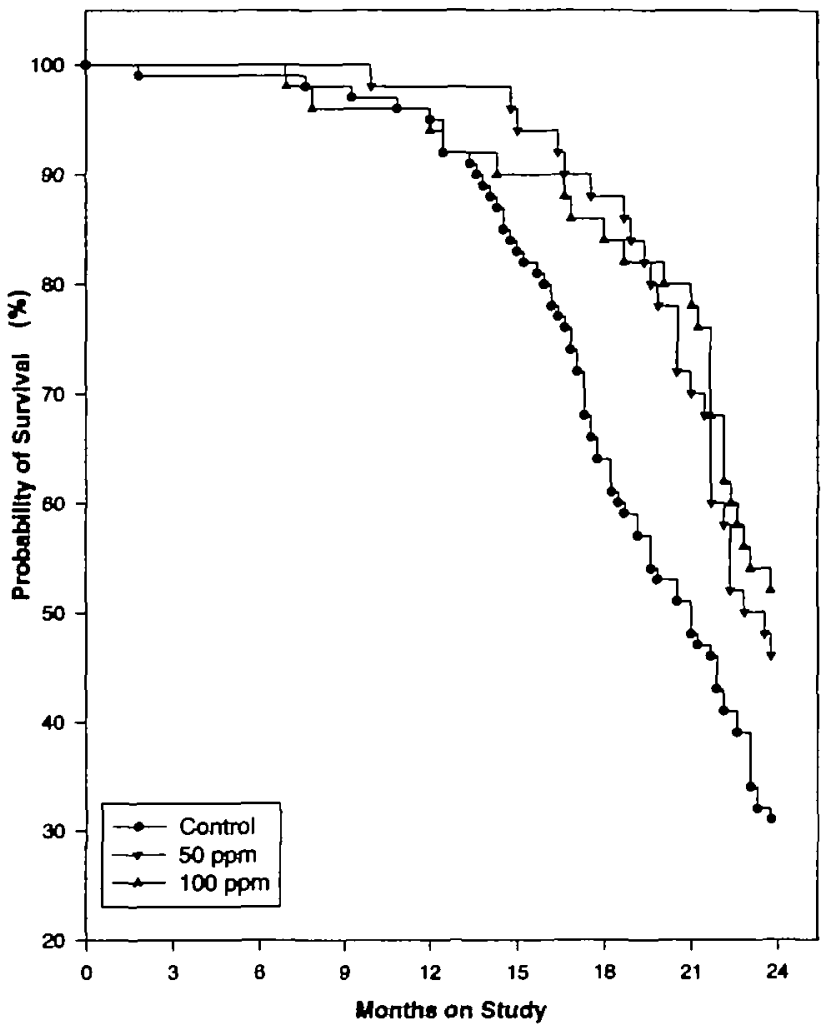

FIG. 10. Kaplan-Meier survival curves: Aroclor 1242 females.

4 months. Although the weight decrease continued for the duration of the study, it was not significant $(p<0.05)$ after 17 months. Dose-related significant decreases in group mean body weights for the 25,50 , and $100 \mathrm{ppm}$ Aroclor 1254 groups were evident beginning at approximately 9, 3, and 1 months, respectively. At 24 months, the differences from control were $10 \%$ for the $100 \mathrm{ppm}$ Aroclor 1242 group, and 15,15 , and $28 \%$ for the 25,50 , and $100 \mathrm{ppm}$ Aroclor 1254 groups, respectively.

There was no treatment-related effect on feed consumption or evidence of poor palatability of the Aroclor-dosed diets. Feed consumption rates $(\mathrm{g} / \mathrm{kg} /$ day $)$ were greater for females than males, but were similar for all groups within each sex. The slightly greater feed consumption rate for females resulted in a correspondingly greater PCB exposure for females in all dose groups (Table 2).

Clinical signs and mortality. No patterns of abnormal behavior or overt signs of toxicity were observed in any treatment group. Palpations for masses, and ophthalmic examinations, did not reveal any patterns attributable to treatment.

Mortality for PCB-exposed males was similar to controls, with the exception of significant increases for the $100 \mathrm{ppm}$ Aroclor 1016 and $50 \mathrm{ppm}$ Aroclor 1254 groups. In no instance was the increased mortality clearly attribut- 


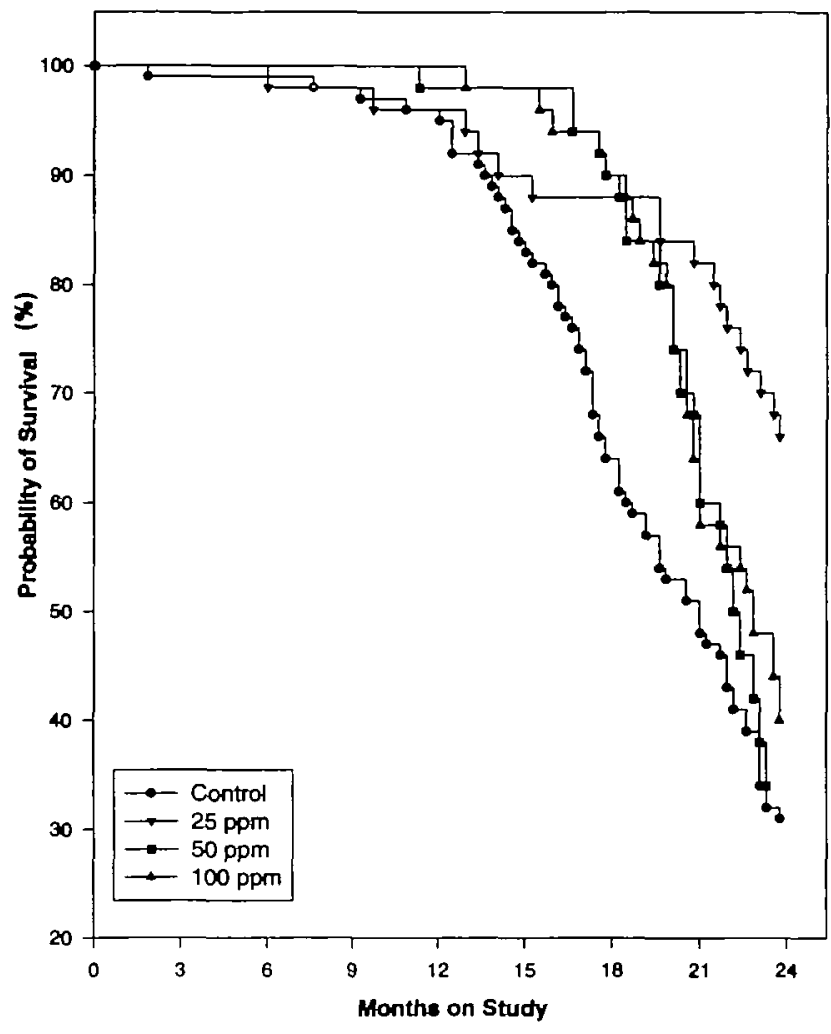

FIG. 11. Kaplan-Meier survival curves: Aroclor 1254 females

able to exposure to PCBs. Survival for PCB-exposed females was greater than the controls for all Aroclor groups, and was significantly increased compared to control for all Aroclor 1016 and Aroclor 1242 groups and for the 25 ppm Aroclor 1254 and 100 ppm Aroclor 1260 dose groups (Figs. 5-12).

Serum chemistry, hematology, and urinalysis. In males, no treatment-related effects on serum chemistry were noted for any groups receiving Aroclors 1016 or 1242. Males receiving Aroclor 1254 had slight increases in serum cholesterol concentrations and males receiving $100 \mathrm{ppm}$ Aroclor 1260 had increased GGT that appeared to be treatment-related (Table 3).

In females, no treatment-related effects on serum chemistry were noted for Aroclor 1016. Dose-related increases in AST, ALT, and GGT were measured for Aroclor 1254, and elevations in AST and GGT were also noted for the $100 \mathrm{ppm}$ dose groups of Aroclors 1242 and 1260. Additionally, treatment-related increases in cholesterol were measured for Aroclors 1242, 1254, and 1260 (Table 3). The increases in total bilirubin measured for Aroclor 1254 were small and were considered equivocally related to treatment.

No treatment-related effects on hematology for males were measured for any groups exposed to Aroclor 1016,
1242 , or 1260 . A slight dose-related decrease in $\mathrm{MCHC}$ was calculated for groups receiving Aroclor 1254, correlating with the slight decrease in $\mathrm{Hb}$ and Hct for the 50 and 100 ppm Aroclor 1254 groups (Table 4).

For females, with the exception of the group receiving 50 ppm Aroclor 1242, decreases in mean RBC count were measured, generally accompanied by concomitant decreases in $\mathrm{Hb}$ concentration and Hct (Table 4). These reductions resulted in associated decreases in the calculated parameters ( $\mathrm{MCV}, \mathrm{MCH}$, and $\mathrm{MCHC}$ ). The greatest reductions were associated with Aroclor 1254, which also produced slightly increased reticulocyte counts for the 50 and $100 \mathrm{ppm}$ dose groups.

No treatment-related effects occurred for ALP, CK, LDH, BUN, creatinine, $\mathrm{Na}^{+}, \mathrm{K}^{+}, \mathrm{Cl}^{-}, \mathrm{Ca}^{2+}$, phosphate, glucose, albumin, total protein, WBCs, or any of the measured urinalysis parameters.

Organ weights. Evaluation of male group mean organ weight data (normalized as organ-to-brain weight ratios to eliminate variability from age- and treatment-related body weight effects) showed treatment-related increases for all Aroclors in liver weight ratios, and in thyroid weight ratios for Aroclors 1242, 1254, and 1260 (Table 5). The magnitude of the effects were generally small and were not clearly dose-related.

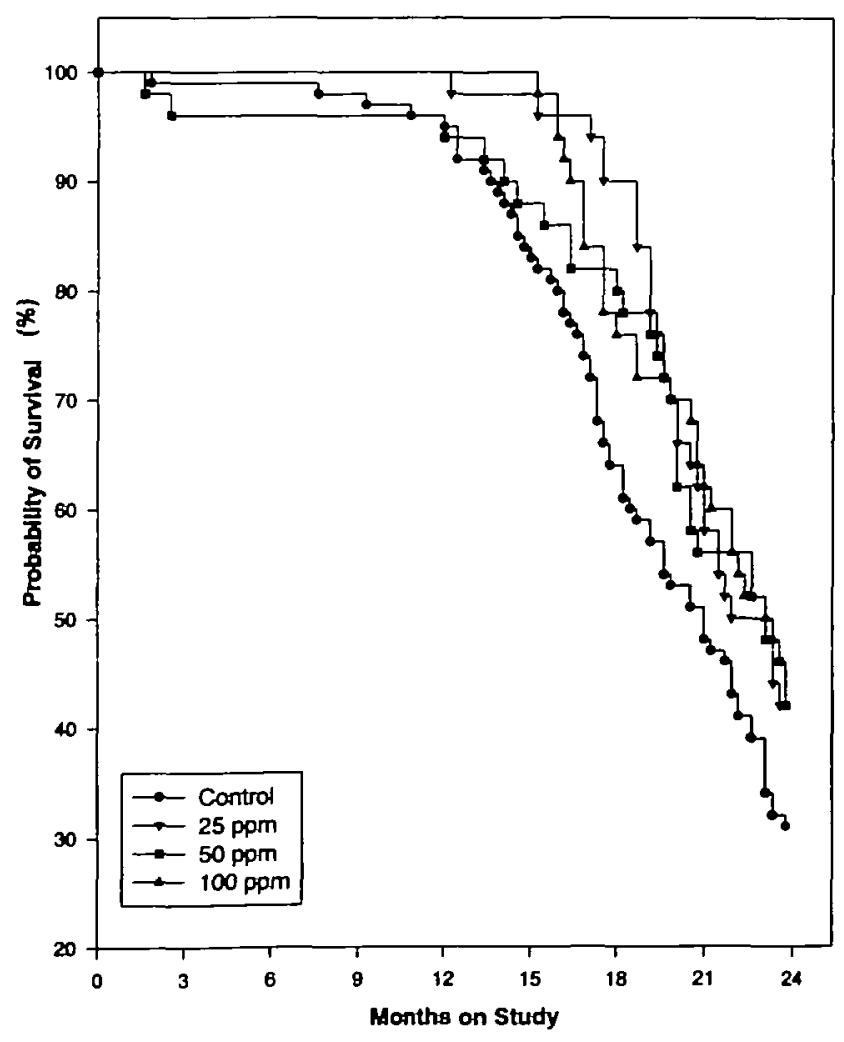

FIG. 12. Kaplan-Meser survival curves: Aroclor 1260 fernales. 
TABLE 3

Serum Chemistries at 24 Months

\begin{tabular}{|c|c|c|c|c|c|c|c|}
\hline Group $^{b}$ & $\begin{array}{c}\text { Dose } \\
(\mathrm{ppm})\end{array}$ & $\operatorname{Sex}$ & $\begin{array}{c}\text { AST } \\
(I U / L)\end{array}$ & $\begin{array}{c}\text { ALT } \\
(\mathrm{IU} / \mathrm{L})\end{array}$ & $\begin{array}{c}\text { GGT } \\
(\mathrm{IU} / \mathrm{L})\end{array}$ & $\begin{array}{c}\text { Total bilirubin } \\
(\mathrm{mg} / \mathrm{dL})\end{array}$ & $\begin{array}{l}\text { Cholesterol } \\
\text { (mg/dL) }\end{array}$ \\
\hline Control & 0 & $\mathbf{M}$ & $86 \pm 35$ & $33 \pm 12$ & $1 \pm 3$ & $0.1 \pm 0.1$ & $157 \pm 84$ \\
\hline \multirow[t]{3}{*}{ Aroclor 1016} & 50 & $\mathbf{M}$ & $93 \pm 33$ & $30 \pm 9$ & $2 \pm 2$ & $0.1 \pm 0.0$ & $176 \pm 91$ \\
\hline & 100 & $\mathbf{M}$ & $81 \pm 25$ & $37 \pm 13$ & $1 \pm 3$ & $0.1 \pm 0.1$ & $217 \pm 94$ \\
\hline & 200 & $\mathbf{M}$ & $81 \pm 21$ & $36 \pm 19$ & $2 \pm 3$ & $0.1 \pm 0.0$ & $210 \pm 71$ \\
\hline \multirow[t]{2}{*}{ Aroclor 1242} & 50 & $\mathbf{M}$ & $85 \pm 25$ & $37 \pm 14$ & $0 \pm 0$ & $0.1 \pm 0.1$ & $208 \pm 94$ \\
\hline & 100 & $\mathbf{M}$ & $94 \pm 23$ & $35 \pm$ & $1 \pm 1$ & $0.1 \pm 0.0$ & $166 \pm 34$ \\
\hline \multirow[t]{3}{*}{ Aroclor 1254} & 25 & $\mathbf{M}$ & $73 \pm 23$ & $37 \pm 14$ & $4 \pm 6$ & $0.1 \pm 0.0$ & $262 \pm 75^{d}$ \\
\hline & 50 & $\mathbf{M}$ & $126 \pm 74$ & $45 \pm 34$ & $2 \pm 1$ & $0.1 \pm 0.1$ & $222 \pm 84$ \\
\hline & 100 & $\mathbf{M}$ & $116 \pm 42$ & $37 \pm 18$ & $3 \pm 2$ & $0.1 \pm 0.0$ & $259 \pm 81^{d}$ \\
\hline \multirow[t]{3}{*}{ Aroclor 1260} & $25^{c}$ & $M$ & $118 \pm 60$ & $49 \pm 28$ & $2 \pm 2$ & $0.1 \pm 0.1^{d}$ & $226 \pm 139$ \\
\hline & 50 & $M$ & $90 \pm 15$ & $33 \pm 9$ & $4 \pm 4$ & $0.1 \pm 0.0^{d}$ & $207 \pm 55$ \\
\hline & 100 & $\mathbf{M}$ & $108 \pm 31$ & $51 \pm 38$ & $11 \pm 12^{d}$ & $0.1 \pm 0.1$ & $207 \pm 50$ \\
\hline Control & 0 & $\mathrm{~F}$ & $132 \pm 46$ & $53 \pm 20$ & $1 \pm 1$ & $0.1 \pm 0.1$ & $136 \pm 35$ \\
\hline \multirow{3}{*}{ Aroclor 1016} & 50 & $\mathrm{~F}$ & $98 \pm 52$ & $34 \pm 24$ & $0 \pm 1$ & $0.1 \pm 0.0$ & $162 \pm 87$ \\
\hline & 100 & $\mathrm{~F}$ & $102 \pm 41$ & $36 \pm 16$ & $2 \pm 2$ & $0.1 \pm 0.1$ & $167 \pm 59$ \\
\hline & 200 & $\mathrm{~F}$ & $95 \pm 32$ & $35 \pm 18$ & $2 \pm 4$ & $0.1 \pm 0.1$ & $180 \pm 56$ \\
\hline \multirow[t]{2}{*}{ Aroclor 1242} & 50 & $F$ & $108 \pm 25$ & $50 \pm 22$ & $2 \pm 3$ & $0.1 \pm 0.1$ & $225 \pm 146$ \\
\hline & 100 & $\mathrm{~F}$ & $212 \pm 148$ & $63 \pm 27$ & $27 \pm 41$ & $0.2 \pm 0.1^{d}$ & $277 \pm 84^{e}$ \\
\hline \multirow[t]{3}{*}{ Aroclor 1254} & 25 & $\mathbf{F}$ & $209 \pm 146$ & $60 \pm 38$ & $26 \pm 38$ & $0.2 \pm 0.1$ & $254 \pm 83^{r}$ \\
\hline & 50 & $\mathrm{~F}$ & $250 \pm 104^{\circ}$ & $175 \pm 161^{d}$ & $62 \pm 5 l^{\circ}$ & $0.2 \pm 0.1^{\epsilon}$ & $360 \pm 139^{\circ}$ \\
\hline & 100 & $\mathrm{~F}$ & $305 \pm 103^{c}$ & $259 \pm 275^{d}$ & $57 \pm 49$ & $0.4 \pm 0.2^{*}$ & $287 \pm 71^{\circ}$ \\
\hline \multirow[t]{3}{*}{ Aroclor 1260} & 25 & $F$ & $141 \pm 75$ & $37 \pm 11^{d}$ & $6 \pm 8$ & $0.1 \pm 0.1$ & $147 \pm 56$ \\
\hline & 50 & $F$ & $126 \pm 64$ & $49 \pm 21$ & $8 \pm 6^{e}$ & $0.1 \pm 0.0$ & $237 \pm 99^{4}$ \\
\hline & 100 & $\mathrm{~F}$ & $273 \pm 434$ & $64 \pm 44$ & $29 \pm 43$ & $0.1 \pm 0.0^{-1}$ & $273 \pm 110^{e}$ \\
\hline
\end{tabular}

Note. Abbreviations used: Aspartate aminotransferase, AST; alanine aminotransferase, ALT; $\gamma$-glutamyl transpeptidase, GGT.

${ }^{\circ}$ Mean \pm SD.

${ }^{b} n=10$, unless otherwise noted.

${ }^{\circ} n=9$.

${ }^{d}$ Statistically significantly different from control at $p \leq 0.05$.

- Statistically significantly different from control at $p \leq 0.01$.

For females, an increase in liver-to-brain weight ratio was similarly apparent for all Aroclors, and was marginally greater than that observed in males. The increase was greatest for Aroclor 1254, followed by Aroclor 1260, Aroclor 1242, and Aroclor 1016 (Table 5). No effects were noted for female thyroid-to-brain weight ratios.

Macroscopic pathology. Treatment-related increases in macroscopically visable lesions were restricted to the liver and thyroid gland for males and to the liver for females. In both sexes, liver abnormalities included enlargement, discoloration (generalized darkening), and foci (local, circumscribed color change), nodules $(<0.5 \mathrm{~cm})$ and masses $(\geq 0.5$ $\mathrm{cm}$ ). In general, the incidence of liver lesions was greatest for females, but in both sexes the trend approximately followed a dose-response pattern, with the greatest incidences found in Aroclor 1254, followed, in order, by Aroclor 1260, Aroclor 1242, and Aroclor 1016. The thyroid glands of male animals receiving Aroclors 1242, 1254, and 1260 were enlarged in a non-dose-related manner. Treatment-related de- creases in mammary gland masses compared to control were recorded for females in one or more groups from each of the four Aroclors evaluated. The reduced incidences of mammary gland masses were not dose-related.

Histopathology (nonneoplastic). The liver was the primary target organ in both males and females. The incidences of nonneoplastic lesions is presented in Table 6. Hepatocellular hypertrophy and hepatic foci, the principal findings, were observed for all Aroclor treatment groups in both males and females. The hepatocellular hypertrophy was most evident in centrilobular regions, with gradual attenuation as the portal triads were approached. Hepatocellular hypertrophy increased in severity in a dose-response manner for each Aroclor. The response for Aroclors 1016, 1242, and 1260 was minimal to mild, and for Aroclor 1254 mild to moderate. The median lobe of the liver was generally slightly more severely affected than the remaining lobes. Hepatocellular hypertrophy was not observed in controls.

For all Aroclors, increased incidences of hepatic foci were 
TABLE 4

Hematology at 24 Months

\begin{tabular}{|c|c|c|c|c|c|c|c|c|c|}
\hline Group & $\begin{array}{l}\text { Dose } \\
\text { (ppm) }\end{array}$ & Sex & $\begin{array}{c}\mathrm{Hb} \\
(\mathrm{g} / \mathrm{dL})\end{array}$ & $\begin{array}{l}\mathrm{Hct} \\
(\mathscr{O})\end{array}$ & $\begin{array}{l}\mathrm{MCV} \\
\text { (fL) }\end{array}$ & $\begin{array}{l}\mathrm{MCH} \\
(\mathrm{pg})\end{array}$ & $\begin{array}{l}\mathrm{MCHC} \\
(\mathrm{g} / \mathrm{dL})\end{array}$ & $\begin{array}{c}\text { Retuculocytes } \\
(\%)\end{array}$ & $\begin{array}{c}\text { RBC } \\
\left(10^{-6} / \mathrm{mL}\right)\end{array}$ \\
\hline Control & 0 & $\mathbf{M}$ & $13.2 \pm 3.3$ & $39.7 \pm 9.8$ & $57 \pm 5$ & $19.1 \pm 1.8$ & $33.4 \pm 1.1$ & $6.6 \pm 13.4$ & $6.92 \pm 1.53$ \\
\hline \multirow{2}{*}{ Aroclor 1016} & 100 & $\mathbf{M}$ & $13.8 \pm 2.5$ & $41.4 \pm 7.2$ & $56 \pm 2$ & $18.8 \pm 0.7$ & $33.3 \pm 0.9$ & $2.0 \pm 1.4$ & $7.31 \pm 1.15$ \\
\hline & 200 & $\mathbf{M}$ & $13.4 \pm 2.2$ & $40.2 \pm 6.5$ & $58 \pm 3$ & $19.3 \pm 1.2$ & $33.3 \pm 0.7$ & $2.7 \pm 1.4$ & $6.97 \pm 1.20$ \\
\hline Aroclor 1242 & 50 & $\mathbf{M}$ & $13.6 \pm 1.7$ & $41.1 \pm 5.0$ & $57 \pm 3$ & $18.8 \pm 0.9$ & $33.0 \pm 0.8$ & $1.9 \pm 1.1$ & $7.22 \pm 0.70$ \\
\hline \multirow{2}{*}{ Aroclor 1254} & 50 & M & $11.8 \pm 1.2$ & $36.8 \pm 3.9$ & $56 \pm 3$ & $17.8 \pm 1.2$ & $32.1 \pm 0.8$ & $2.4 \pm 1.0$ & $6.65 \pm 0.86$ \\
\hline & 100 & $\mathbf{M}$ & $11.8 \pm 1.0$ & $36.8 \pm 3.2$ & $54 \pm 3$ & $17.2 \pm 0.9^{d}$ & $31.9 \pm 0.4^{e}$ & $2.7 \pm 0.9$ & $6.82 \pm 0.61$ \\
\hline \multirow[t]{3}{*}{ Aroclor 1260} & $25^{c}$ & $\mathbf{M}$ & $12.5 \pm 1.7$ & $38.4 \pm 5.5$ & $56 \pm 3$ & $18.2 \pm 0.7$ & $32.5 \pm 0.7^{4}$ & $1.9 \pm 0.5$ & $6.85 \pm 1.00$ \\
\hline & 50 & $\mathbf{M}$ & $12.7 \pm 1.8$ & $38.9 \pm 5.3$ & $57 \pm 4$ & $18.8 \pm 1.4$ & $32.8 \pm 0.3$ & $2.0 \pm 1.8$ & $6.80 \pm 0.92$ \\
\hline & 100 & $\mathbf{M}$ & $124 \pm 1.0$ & $38.3 \pm 3.0$ & $55 \pm 2$ & $17.9 \pm 0.7$ & $32.5 \pm 1.0$ & $2.1 \pm 0.9$ & $6.96 \pm 0.64$ \\
\hline Control & 0 & $\mathrm{~F}$ & $15.3 \pm 1.5$ & $45.4 \pm 4.5$ & $62 \pm 3$ & $20.8 \pm 1.0$ & $33.6 \pm 0.5$ & $1.7 \pm 0.4$ & $7.36 \pm 0.81$ \\
\hline Aroclor 1242 & 100 & $\mathrm{~F}$ & $12.1 \pm 2.7^{d}$ & $35.7 \pm 82^{e}$ & $57 \pm 4^{d}$ & $19.3 \pm 1.2^{d}$ & $34.1 \pm 0.9$ & $3.8 \pm 5.6$ & $6.30 \pm 1.45$ \\
\hline \multirow{3}{*}{ Aroclor 1254} & 25 & $\mathrm{~F}$ & $12.5 \pm 1.3^{e}$ & $36.8 \pm 3.6^{e}$ & $54 \pm 3^{e}$ & $18.5 \pm 1.2^{\circ}$ & $340 \pm 0.7$ & $1.9 \pm 0.8$ & $6.77 \pm 0.55$ \\
\hline & 50 & $\mathrm{~F}$ & $11.0 \pm 1.6^{\circ}$ & $32.8 \pm 4.0^{\circ}$ & $53 \pm 4^{r}$ & $17.7 \pm 1.7^{e}$ & $33.3 \pm 0.9$ & $3.0 \pm 0.9$ & $6.19 \pm 0.66^{\circ}$ \\
\hline & 100 & $\mathrm{~F}$ & $10.9 \pm 0.9^{\circ}$ & $32.2 \pm 2.5^{\circ}$ & $54 \pm 4^{e}$ & $18.5 \pm 1.4^{\circ}$ & $33.9 \pm 0.7$ & $4.0 \pm 1.5^{\circ}$ & $5.95 \pm 0.66^{\circ}$ \\
\hline \multirow[t]{3}{*}{ Aroclor 1260} & 25 & $\mathrm{~F}$ & $12.9 \pm 1.5$ & $38.1 \pm 5.1^{\circ}$ & $61 \pm 3$ & $20.7 \pm 1.5$ & $34.0 \pm 1.1$ & $2.5 \pm 1.7$ & $6.30 \pm 0.97^{\alpha}$ \\
\hline & 50 & $\mathrm{~F}$ & $12.3 \pm 2.0^{\circ}$ & $36.7 \pm 5.9^{\circ}$ & $58 \pm 3^{d}$ & $19.6 \pm 1.2^{d}$ & $33.6 \pm 0.5$ & $1.8 \pm 0.8$ & $6.30 \pm 1.04$ \\
\hline & 100 & $\mathrm{~F}$ & $11.4 \pm 2.6^{\circ}$ & $33.6 \pm 8.1^{e}$ & $61 \pm 11$ & $20.9 \pm 4.3$ & $33.9 \pm 1.0$ & $5.5 \pm 11.6$ & $5.76 \pm 1.84^{d}$ \\
\hline
\end{tabular}

Note. Abbreviatıons used: Hemoglobin concentration, $\mathrm{Hb}$; hematocrit, Hct; mean cell volume, $\mathrm{MCV}$; mean cell hemoglobın, $\mathrm{MCH}$; mean cell hemoglobin concentratıon, MCHC; red blood cell count, RBC.

${ }^{a}$ Mean \pm SD.

${ }^{B} n=10$, unless otherwise noted.

${ }^{c} n=9$.

Statistically significantly different from control at $p \leq 0.05$.

- Statistucally significantly different from control at $p \leq 0.01$.

identified more frequently in females than in males, and occurred at a generally similar incidence for Aroclors 1242, 1254 , and 1260 , and at a slightly reduced incidence for Aroclor 1016. Eosinophilic foci were the most prevalent form, with clear cell, mixed cell, and basophilic foci also being increased, but to a much lesser extent.

The occurrences of hepatocyte vacuolization and bile duct hyperplasia were also increased in males and females dosed with Aroclor 1242, 1254, or 1260, and in females only for Aroclor 1016. Females also showed an increased incidence of liver pigment, especially in animals receiving Aroclor 1242 or 1254 . The pigment, which was gray/brown in color, was localized in the sinusoidal lining cells and generally filled the cytoplasm of affected cells.

The incidence of follicular cell hyperplasia in the thyroid gland (generally minimal or mild) was increased in a non dose-related pattern for males exposed to Aroclors 1242, 1254, and 1260 (Table 7).
Histopathology (neoplastic). Sex-dependent significant increases in tumor responses were noted for liver (hepatocellular adenoma and carcinoma, hepatocholangioma, and hepatocholangiocarcinoma), and thyroid gland (follicular cell adenoma), while significant decreases were measured for mammary gland (fibroadenoma, adenoma, and adenocarcinoma) (Tables 7-10). For males, the response in liver was restricted to a single dose group, $100 \mathrm{ppm}$ Aroclor 1260 . Slight, non-dose-related, increases in the incidence of thyroid gland follicular cell adenomas were measured for males receiving Aroclors 1242, 1254, and 1260.

For females, a significant and generally dose-related increase in the incidence of hepatic neoplasms (primarily adenomas) was measured for all treatment groups, except 50 ppm Aroclor 1016. The magnitude of the increases was greatest for Aroclor 1254, followed by Aroclor $1260 \approx$ Aroclor $1242>$ Aroclor 1016. The number of animals with multiple hepatocellular adenomas increased in a dose-re- 
TABLE 5

Organ to Brain Weight Ratios (\%) for Liver and Thyroid Gland at 24 Months

\begin{tabular}{|c|c|c|c|c|c|}
\hline Group & $\begin{array}{l}\text { Dose } \\
\text { (ppm) }\end{array}$ & Liver & Thyroid & Liver & Thyroid \\
\hline \multirow{3}{*}{ Aroclor 1016} & 50 & $1070 \pm 441(14)$ & $2.1 \pm 0.5$ & $853 \pm 285(20)$ & $2.3 \pm 0.5$ \\
\hline & 100 & $1237 \pm 466(14)$ & $2.7 \pm 1.4$ & $970 \pm 207(21)^{6}$ & $1.9 \pm 0.3$ \\
\hline & 200 & $1216 \pm 239(25)$ & $2.3 \pm 0.6$ & $980 \pm 247(24)^{4}$ & $2.3 \pm 0.7$ \\
\hline \multirow[t]{3}{*}{ Aroclor 1254} & 25 & $1346 \pm 273$ & $2.9 \pm 0.5^{d}$ & $1206 \pm 427(33)^{\circ}$ & $2.7 \pm 1.2$ \\
\hline & 50 & $1304 \pm 240(11)$ & $8.4 \pm 1 \gamma^{f}$ & $1584 \pm 553(17)^{c}$ & $2.2 \pm 0.4$ \\
\hline & 100 & $1411 \pm 327(20)$ & $6.4 \pm 12$ & $1722 \pm 557(20)^{c}$ & $2.0 \pm 0.4$ \\
\hline \multirow[t]{2}{*}{ Aroclor 1260} & 25 & $1316 \pm 375(24)$ & $3.0 \pm 0.7^{d}$ & $984 \pm 279(19)^{d}$ & $6.0 \pm 12^{\prime}$ \\
\hline & 50 & $1336 \pm 248(16)$ & $2.6 \pm 0.5$ & $1086 \pm 272(21)^{e}$ & $2.2 \pm 0.6$ \\
\hline
\end{tabular}

- Mean \pm SD

${ }^{b} n=10$ for thyroid gland.

' Number in parentheses is $n$ for liver.

- Statisucally significantly different from control at $p \leq 0.05$.

- Statistically significantly different from control at $p \leq 0.01$.

${ }^{f}$ Includes one animal with thyroid tumor.

sponse manner for all Aroclors, and was most pronounced for the 50 and $100 \mathrm{ppm}$ dose groups of Aroclor 1254 and the $100 \mathrm{ppm}$ dose group of Aroclor 1260, which were also the groups with the greatest total incidences of hepatocellular neoplastic response. With the exception of one female in the $100 \mathrm{ppm}$ Aroclor 1260 dose group, the liver neoplasms did not metastasize. No increases in thyroid gland neoplasms were noted for females.

A significantly decreased trend in the incidence for spontaneously occurring mammary gland tumors in females was measured for Aroclors 1242, 1254, and 1260 (Table 10).

\section{DISCUSSION}

The current study is the most comprehensive chronic toxicity and oncogenicity evaluation of PCBs ever reported. Previously, the tumorigenic potency of PCBs was estimated by the EPA to have a cancer slope factor of $7.7(\mathrm{mg} /$ $\mathrm{kg} \cdot$ day) $)^{-1}$, based upon the findings with Aroclor 1260 in a 1985 study by Norback and Weltman (U.S. Environmental Protection Agency, 1988). The upper-bound cancer slope factors calculated from the current, and more complete, data set range from 0.07 to $1.5\left(\mathrm{mg} / \mathrm{kg} \cdot\right.$ day) ${ }^{-1}$ (U.S. Environmental Protection Agency, 1996), a clear indication that the carcinogenic potency of PCBs is less than previously assumed.

The exposure of male and female Sprague-Dawley rats to Aroclors 1016, 1242, 1254, and 1260 for 2 years did not result in any changes in appearance or behavior that were suggestive of systemic toxicity. In chronic studies, decreases in body weight gain patterns and/or increased mortality are predictive indicators of systemic toxicity. In the current study biologically meaningful decreases in body weight gains were confined to only groups receiving Aroclor 1254 , especially females. The absence of a morbid response is further reinforced by the lack of treatmentrelated mortality in males and the increased survivability exhibited for all groups of females receiving Aroclors.

In this and previous chronic studies of PCBs, the principal target organ for toxicity in rats is the liver. Significant dose-related increases in group mean liver weights were measured for females $(24-120 \%)$, while for males the increases were small $(\leq 20 \%)$ and were not dose-related. These weight increases correlated with hepatocellular hypertrophy which, in turn, was associated with induction of mixed-function oxidases, a well-known consequence of PCB exposure in rats, and which has been confirmed for the current study (Fish et al., 1997).

Significant liver toxicity was restricted almost exclusively to females. It was manifested by increases in cellular enzyme leakage associated with membrane disruption (AST, ALT), bile duct proliferation (GGT), altered lipid metabolism (cholesterol), and by hematologic changes (decreases in RBC count, $\mathrm{Hb}$ concentration, and $\mathrm{Hct}$ ), which was presumably the result of decreased erythropoietinogen production by the liver, or possibly, of decreased hepatic 
TABLE 6

Incidence of Selected Nonneoplastic Liver Lesions

\begin{tabular}{|c|c|c|c|c|c|c|c|c|c|c|}
\hline Group & $\begin{array}{c}\text { Dose } \\
(\mathrm{ppm})\end{array}$ & Sex & $\begin{array}{l}\text { Pigment } \\
(\%)\end{array}$ & $\begin{array}{c}\text { Centrilobular } \\
\text { hypertrophy } \\
(\%)\end{array}$ & $\begin{array}{c}\text { Bile duct } \\
\text { hyperplasia } \\
(\%)\end{array}$ & $\begin{array}{c}\text { Hepatocyte } \\
\text { vacuolization } \\
(\%)\end{array}$ & $\begin{array}{l}\text { Basophilic } \\
\text { focus }(\%)\end{array}$ & $\begin{array}{l}\text { Clear cell } \\
\text { focus }(\%)\end{array}$ & $\begin{array}{l}\text { Eosinophilic } \\
\text { focus }(\mathscr{\phi})\end{array}$ & $\begin{array}{l}\text { Mixed cell } \\
\text { focus }\left(q_{b}\right)\end{array}$ \\
\hline Control" & 0 & $\mathbf{M}$ & $0(0)$ & $0(0)$ & $70(70)$ & $32(32)$ & $7(7)$ & $17(17)$ & $2(2)$ & $5(5)$ \\
\hline \multirow[t]{3}{*}{ Aroclor 1016} & 50 & $\mathbf{M}$ & $0(0)$ & $18(36)$ & $38(76)$ & $18(36)$ & $3(6)$ & $1(2)$ & $5(10)$ & $1(2)$ \\
\hline & 100 & $\mathbf{M}$ & $0(0)$ & $34(68)$ & $35(70)$ & $18(36)$ & $5(10)$ & $3(6)$ & $2(4)$ & $4(8)$ \\
\hline & 200 & $\mathbf{M}$ & $0(0)$ & $44(88)$ & $37(74)$ & $22(44)$ & $2(4)$ & $9(18)$ & $6(12)$ & $2(4)$ \\
\hline \multirow[t]{2}{*}{ Aroclor 1242} & 50 & $M$ & $0(0)$ & $41(82)$ & $45(90)$ & $25(50)$ & $2(4)$ & $7(14)$ & $9(18)$ & $11(22)$ \\
\hline & 100 & M & $0(0)$ & $45(90)$ & $40(80)$ & $36(72)$ & $2(4)$ & $4(8)$ & $8(16)$ & 7 (14) \\
\hline \multirow[t]{3}{*}{ Aroclor 1254} & 25 & $\mathbf{M}$ & $0(0)$ & $41(82)$ & $43(86)$ & $37(74)$ & $3(6)$ & $11(22)$ & $14(28)$ & $18(36)$ \\
\hline & 50 & $\mathbf{M}$ & $0(0)$ & $49(98)$ & $46(92)$ & $42(84)$ & $2(4)$ & $11(22)$ & $12(24)$ & $6(12)$ \\
\hline & 100 & $\mathbf{M}$ & $0(0)$ & $47(94)$ & $46(92)$ & $45(90)$ & $2(4)$ & $17(34)$ & $13(26)$ & $5(10)$ \\
\hline \multirow[t]{3}{*}{ Aroclor 1260} & 25 & $\mathbf{M}$ & $0(0)$ & $44(88)$ & $45(90)$ & $36(72)$ & $3(6)$ & $8(16)$ & $11(22)$ & $13(26)$ \\
\hline & 50 & $\mathbf{M}$ & $0(0)$ & $45(90)$ & $53(86)$ & $24(48)$ & $3(6)$ & $4(8)$ & $18(36)$ & $10(20)$ \\
\hline & 100 & $\mathbf{M}$ & $0(0)$ & $42(84)$ & $40(80)$ & $32(64)$ & $1(2)$ & $5(10)$ & $12(24)$ & $13(26)$ \\
\hline Control & 0 & $\mathrm{~F}$ & $7(7)$ & $0(0)$ & $40(40)$ & $13(13)$ & $5(5)$ & $2(2)$ & $4(4)$ & $8(8)$ \\
\hline \multirow[t]{3}{*}{ Aroclor 1016} & 50 & $\mathbf{F}$ & $2(4)$ & $21(42)$ & $28(56)$ & $15(30)$ & $12(24)$ & $3(6)$ & $12(24)$ & $5(10)$ \\
\hline & 100 & $\mathbf{F}$ & $3(6)$ & $30(60)$ & $31(62)$ & $17(34)$ & $11(22)$ & $1(2)$ & $13(26)$ & $9(18)$ \\
\hline & 200 & $\mathbf{F}$ & $7(14)$ & $42(84)$ & $43(86)$ & $17(34)$ & $12(24)$ & $2(4)$ & $24(48)$ & $6(12)$ \\
\hline \multirow[t]{2}{*}{ Aroclor 1242} & 50 & $\mathbf{F}$ & $14(28)$ & $44(88)$ & $42(84)$ & $33(66)$ & $16(32)$ & $7(14)$ & $38(76)$ & $21(42)$ \\
\hline & 100 & $\mathbf{F}$ & $13(26)$ & $44(88)$ & $44(88)$ & $28(56)$ & $10(20)$ & $8(16)$ & $39(78)$ & $19(38)$ \\
\hline \multirow[t]{3}{*}{ Aroclor 1254} & $25^{b}$ & $F$ & $9(18)$ & $48(96)$ & $44(88)$ & $36(72)$ & $9(18)$ & $3(6)$ & $43(86)$ & $19(38)$ \\
\hline & 50 & $\mathrm{~F}$ & $16(32)$ & $46(92)$ & $46(92)$ & $41(82)$ & $5(10)$ & $3(6)$ & $40(80)$ & $20(40)$ \\
\hline & 100 & $\mathbf{F}$ & $21(42)$ & $49(98)$ & $48(96)$ & $43(86)$ & $5(10)$ & $4(8)$ & $46(92)$ & $24(48)$ \\
\hline \multirow[t]{3}{*}{ Aroclor 1260} & 25 & $\mathbf{F}$ & $12(24)$ & $41(82)$ & $40(80)$ & $18(36)$ & $6(12)$ & $2(4)$ & $31(62)$ & $9(18)$ \\
\hline & 50 & $\mathbf{F}$ & $8(16)$ & $42(84)$ & $44(88)$ & $23(46)$ & $11(22)$ & $0(0)$ & $36(72)$ & $12(24)$ \\
\hline & 100 & $F$ & $3(6)$ & $42(84)$ & $44(88)$ & $28(56)$ & $5(10)$ & $2(4)$ & $36(72)$ & $18(36)$ \\
\hline
\end{tabular}

${ }^{\circ} n=100$ for control, all other groups $n=50$.

${ }^{b} n=49$.

retinoid concentrations (Chen et al., 1992; Sauberlich and Hodges, 1997). The hematologic changes were small and were generally not sufficient to induce an increased release of reticulocytes.
The current study clearly indicates that the hepatic tumor response to PCBs in Sprague-Dawley rats is sexdependent. The tumorigenic response in females was Aroclor- and dose-dependent, while the response in males was

TABLE 7

Incidence of Selected Nonneoplastic and Neoplastic Thyroid Gland Lesions for Males

\begin{tabular}{|c|c|c|c|c|c|}
\hline Group & $\begin{array}{c}\text { Dose } \\
\text { (ppm) }\end{array}$ & $\begin{array}{c}\text { Follicular cell } \\
\text { hyperplasia }(\%)\end{array}$ & $\begin{array}{l}\text { Follicular cell } \\
\text { adenoma }(\$)\end{array}$ & $\begin{array}{l}\text { Follicular cell } \\
\text { carcinoma }(\%)\end{array}$ & $\begin{array}{l}\text { Total males } \\
\text { with neoplasms }\left(\Phi_{0}\right)\end{array}$ \\
\hline Control & 0 & $1(1)$ & $1(1)$ & $1(1)$ & $2(2)$ \\
\hline \multirow[t]{3}{*}{ Aroclor 1016} & 50 & $1(2)$ & $3(6)$ & $1(2)$ & $4(8)$ \\
\hline & 100 & $3(6)$ & $2(4)$ & $1(2)$ & $3(6)$ \\
\hline & 200 & $1(2)$ & $0(0)$ & $1(2)$ & $1(2)$ \\
\hline \multirow[t]{2}{*}{ Arnclor 1242} & 50 & $4(8)$ & $5(10)^{c}$ & $2(4)$ & $7(14)^{\prime}$ \\
\hline & 100 & $3(6)$ & $5(10)^{c}$ & $1(2)$ & $6(12)^{r}$ \\
\hline \multirow[t]{3}{*}{ Aroclor 1254} & 25 & $12(24)$ & $6(12)^{d}$ & $1(2)$ & $7(14)^{d}$ \\
\hline & 50 & $6(12)$ & $4(8)^{c}$ & $3(6)$ & $7(14)^{d}$ \\
\hline & 100 & $6(12)$ & $5(10)^{c}$ & $1(2)$ & $6(12)^{c}$ \\
\hline \multirow[t]{3}{*}{ Aroclor 1260} & 25 & $6(12)$ & $6(12)^{d}$ & $1(2)$ & $7(14)^{d}$ \\
\hline & 50 & $9(18)$ & $4(8)^{c}$ & $1(2)$ & $5(10)^{c}$ \\
\hline & 100 & $5(10)$ & $3(6)$ & $1(2)$ & $4(8)$ \\
\hline
\end{tabular}

${ }^{a} n=100$ for control, all other groups $n=50$.

${ }^{b}$ Follicular cell adenoma or carcinoma.

c Statistically significantly different from control at $p \leq 0.05$ (Fisher's exact test).

- Statistically significantly different from control at $p \leq 0.01$ (Fisher's exact test) 
TABLE 8

Incidence of Neoplastic Liver Lesions

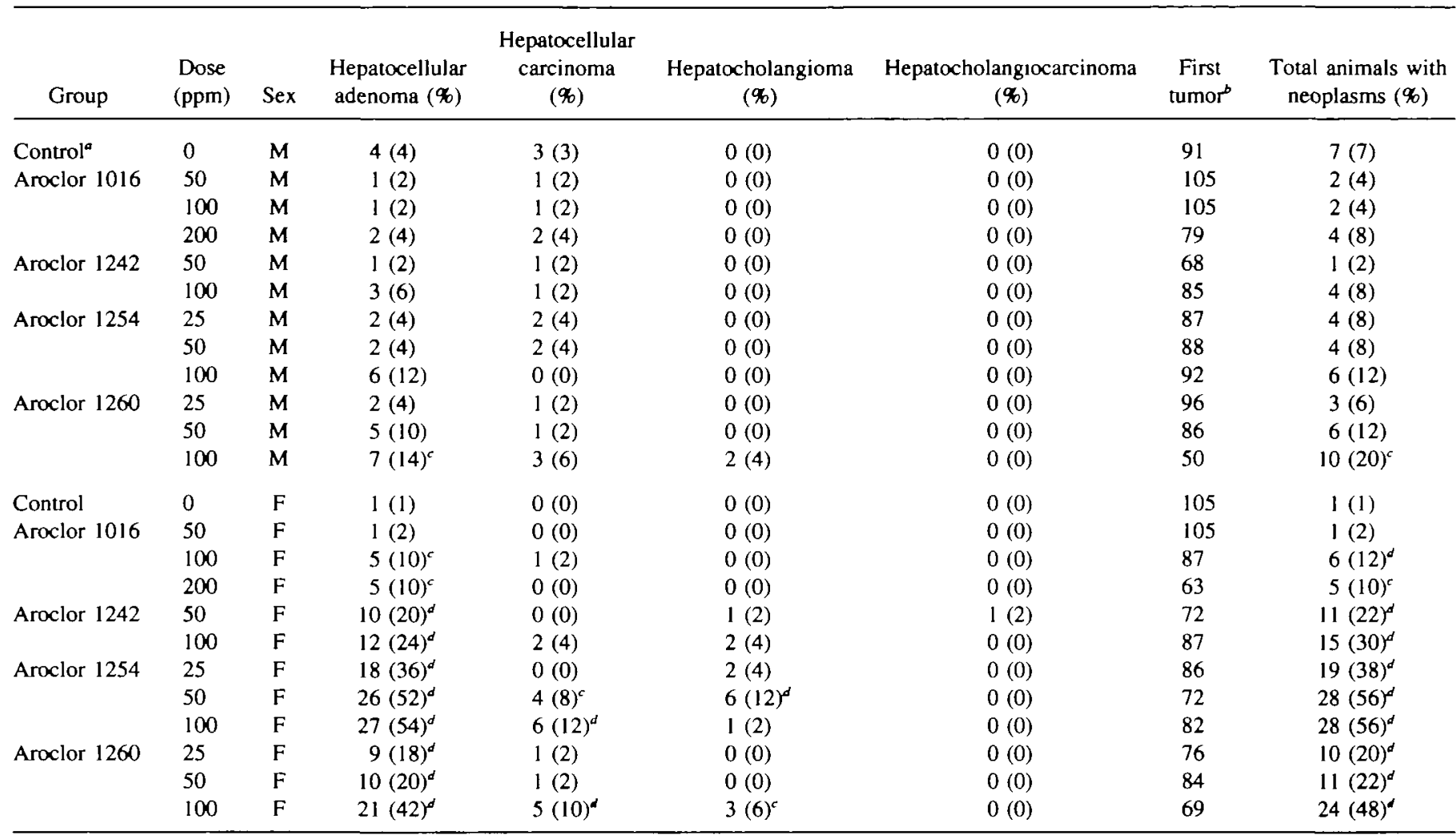

$a_{n}=100$ for control, all other groups $n=50$.

${ }^{b}$ Study week of first occurrence.

' Statistically significantly different from control at $p \leq 0.05$ (Fisher's exact test).

'Statisucally significantly different from control at $p \leq 001$ (Fisher's exact test)

nonsignificant for all groups, except the group receiving the highest dose of Aroclor 1260 (100 ppm). The overwhelming majority of the tumors induced were benign hepatocellular adenomas (80\%), with smaller numbers of hepatocellular carcinomas $(11 \%)$, hepatocholangiomas $(8 \%)$, and hepatocholangiocarcinomas $(<1 \%)$. These neoplasms did not adversely impact treatment-group survival rates because, for all Aroclor-exposed groups of females, survival was greater for treatment groups than for controls. For females, the tumor incidence differed between Aroclor mixtures in a manner that paralleled the differences between Aroclors in total TEQ (calculated as per Ahlborg (1994)), i.e., Aroclor $1254>$ Aroclor $1260 \approx$ Aroclor $1242>$ Aroclor 1016 (Table 1). A more complete description of the correlation of hepatic TEQ and PCB accumulation with tumor incidence for males and females has been reported by Silkworth et al. (1997). The composition of Aroclor 1254 used in the current study contained twice the TEQ of the product that was generally used in commercial applications. Therefore, the response for females in this study overrepresents the response that would have been expected for ordinary Aroclor 1254.

The liver tumor response rate for females receiving Aroclor 1254 in the current study $(38,56$, and $56 \%$ for the 25 , 50 , and $100 \mathrm{ppm}$ dose groups, respectively) was also much greater than that observed in a study conducted by the NCI (1978), wherein liver tumor incidence rates of 4,8 , and $4 \%$ were recorded at dietary doses of 25,50 , and $100 \mathrm{ppm}$, respectively (Moore et al., 1994). The reason for the disparate tumor response rates is unknown, but a differential sensitivity between the rat strains used in the two studies (Fisher 344 vs Sprague-Dawley) is clearly a possibility. Another difference between the studies may be the composition of Aroclor 1254 used, i.e., lot KB01-604, produced• in 1971, versus lot KI-02-6024, produced in 1976 and subsequently modified (see Table 1).

A slight, non-dose-related, increase in the incidence of thyroid gland follicular cell adenomas was observed in males receiving Aroclors 1242, 1254, and 1260. The background incidence of this tumor type in male Sprague- 
TABLE 9

Incidence of Multiple Neoplastic Liver Lesions

\begin{tabular}{|c|c|c|c|c|}
\hline Group & $\begin{array}{c}\text { Dose } \\
(\mathrm{ppm})\end{array}$ & Sex & $\begin{array}{c}\text { Multiple } \\
\text { hepatocellular } \\
\text { adenomas (\%) }\end{array}$ & $\begin{array}{c}\text { Multiple } \\
\text { hepatocellular } \\
\text { carcinomas (\%) }\end{array}$ \\
\hline Control & 0 & $\mathbf{M}$ & $0(0)$ & $0(0)$ \\
\hline \multirow[t]{3}{*}{ Aroclor 1016} & 50 & $\mathbf{M}$ & $0(0)$ & $0(0)$ \\
\hline & 100 & $\mathbf{M}$ & $0(0)$ & $0(0)$ \\
\hline & 200 & $\mathbf{M}$ & $0(0)$ & $0(0)$ \\
\hline \multirow[t]{2}{*}{ Aroclor 1242} & 50 & $\mathbf{M}$ & $0(0)$ & $0(0)$ \\
\hline & 100 & $\mathbf{M}$ & $0(0)$ & $0(0)$ \\
\hline \multirow[t]{3}{*}{ Aroclor 1254} & 25 & $M$ & $0(0)$ & $0(0)$ \\
\hline & 50 & M & $0(0)$ & $0(0)$ \\
\hline & 100 & $\mathbf{M}$ & $2(4)$ & $0(0)$ \\
\hline \multirow[t]{3}{*}{ Aroclor 1260} & 25 & $\mathbf{M}$ & $0(0)$ & $0(0)$ \\
\hline & 50 & $\mathbf{M}$ & $2(4)$ & $0(0)$ \\
\hline & 100 & $\mathbf{M}$ & $3(6)^{b}$ & $1(2)$ \\
\hline Control & 0 & F & $0(0)$ & $0(0)$ \\
\hline \multirow[t]{3}{*}{ Aroclor 1016} & 50 & $\mathrm{~F}$ & $0(0)$ & $0(0)$ \\
\hline & 100 & $\mathrm{~F}$ & $1(2)$ & $0(0)$ \\
\hline & 200 & F & $3(6)^{b}$ & $0(0)$ \\
\hline \multirow[t]{2}{*}{ Aroclor 1242} & 50 & $\mathrm{~F}$ & $3(6)^{b}$ & $0(0)$ \\
\hline & 100 & $\mathrm{~F}$ & $7(14)^{c}$ & $0(0)$ \\
\hline \multirow{3}{*}{ Aroclor 1254} & 25 & $\mathrm{~F}$ & $9(18)^{c}$ & $0(0)$ \\
\hline & 50 & $F$ & $15(30)^{c}$ & I (2) \\
\hline & 100 & $\mathrm{~F}$ & $21(42)^{c}$ & $4(8)^{b}$ \\
\hline \multirow[t]{3}{*}{ Aroclor 1260} & 25 & $\mathrm{~F}$ & $6(12)^{c}$ & $0(0)$ \\
\hline & 50 & $\mathrm{~F}$ & $8(16)^{c}$ & $0(0)$ \\
\hline & 100 & $\mathrm{~F}$ & $16(32)^{c}$ & $1(2)$ \\
\hline
\end{tabular}

${ }^{a} n=100$ for control, all other groups $n=50$.

${ }^{b}$ Statıstically significantly different from control at $p \leq 0.05$ (Fisher's exact test).

'Statistically significantly different from control at $p \leq 0.01$ (Fisher's exact test).
Dawley rats is approximately 4\% (Keenan et al., 1995). The morphologic appearance of the thyroid tumors were characteristic of those that develop as a secondary response to chronic overstimulation by thyroid-stimulating hormone (TSH). This phenomonon is more common in males than female rats due to higher circulating levels of TSH in males (Capen 1996). Oversecretion of TSH results when hepatic enzyme induction accelerates the metabolism of T3 and $\mathrm{T} 4$, with subsequent loss of feedback inhibition within the hypothalamic-pituitary-thyroid axis (Curran and DeGroot, 1991). PCBs are very effective hepatic mixed-function oxidase enzyme inducers, and presumably produce thyroid tumors in male rats through hypersecretion of TSH as described above.

The incidence of spontaneous mammary tumors in untreated female Sprague-Dawley rats is high, $54 \%$ in the current study with even higher rates $(67-94 \%)$ being reported by others (Keenan et al., 1995; Kociba et al., 1978). In a study by Kimbrough et al. (1975), administration of Aroclor 1260 to Sherman rats resulted in a reduced incidence of mammary tumors. The results of the current study are consistent with this finding because the rate of spontaneous mammary tumors in PCB-exposed females was decreased. The decreases were most consistently observed for groups receiving Aroclors 1242 and 1260, although decreases were also observed for some groups receiving Aroclors 1016 and 1254. The decreased tumor rates may be the result of an alteration in the 2-hydroxylation versus $16 \alpha$-hydroxylation ratio of estrogen (Bradlow et al., 1995; Fishman et al., 1995), which has been demonstrated for the current study (Amaratunga et al., 1997).

TABLE 10

Incidence of Neoplastic Mammary Gland Lesions for Females

\begin{tabular}{|c|c|c|c|c|c|c|}
\hline Control $^{\sigma}$ & 0 & $34(34)$ & $14(28)$ & $15(30)$ & 40 & $54(54)$ \\
\hline \multirow{2}{*}{ Aroclor 1016} & 100 & $15(30)$ & $9(18)$ & $8(16)$ & 51 & $28(56)$ \\
\hline & 200 & $20(40)$ & $9(18)$ & $2(4)$ & 63 & $28(56)$ \\
\hline Aroclor 1242 & 50 & $17(34)$ & $3(6)$ & $2(4)$ & 64 & $19(38)$ \\
\hline \multirow{2}{*}{ Aroclor 1254} & 50 & $29(58)^{c}$ & $3(6)$ & $3(6)$ & 49 & $34(68)$ \\
\hline & $100^{b}$ & $10(20)$ & $3(6)$ & $1(2)^{d}$ & 69 & $13(27)^{6}$ \\
\hline \multirow[t]{3}{*}{ Aroclor 1260} & $25^{b}$ & $10(20)$ & $5(10)$ & $4(8)$ & 66 & $17(35)^{d}$ \\
\hline & 50 & $13(26)$ & $5(10)$ & $3(6)$ & 78 & $18(36)^{d}$ \\
\hline & 100 & $14(28)$ & $2(4)$ & $6(12)$ & 66 & $20(40)$ \\
\hline
\end{tabular}

Note: Statistically significant negative trends for mammary gland neoplasms ( $p \leq 0.05$ ) occurred for Aroclors 1242, 1254, and 1260.

- $n=100$ for control, all other groups $n=50$.

$b_{n}=49$.

' Study week of first occurrence.

- Statistically significantly different from control at $p \leq 0.05$ (Fisher's exact test).

' Statistically significantly different from control at $p \leq 0.01$ (Fisher's exact test). 
In summary, the results of this study indicate that PCBs have sex-dependent tumor-suppressing and tumor-enhancing activities in Sprague-Dawley rats. Tumor repression occurred in the mammary glands of the females. Tumor enhancement occurred in the thyroid gland of the males and the liver of both sexes, but primarily in the liver of the females. The tumors that were produced were mostly benign and did not curtail the natural life span of the animals. The study also shows that PCBs differ in tumor-inducing potency, and supports the use of PCBspecific cancer slope factors for scientifically based risk assessments.

\section{REFERENCES}

Ahlborg, U. G., Becking, G. C., Bimbaum, L. S., Brouwer, A , Derks, H. J. G. M., Feeley, M., Golor, F., Hanberg, A., Larsen, J. C., Liem, A. K. D., et al. (1994). Toxic equivalency factors for dioxin-like PCBs. Chemos. 28, 1049-1067.

Amaratunga, M., Fish, K. M., Brown, J. F., Jr., Mayes, B. A., Malone, J., May, R. J., and Silkworth, J. B. (1997). Estrogen metabolism by hepatic microsomes from rats chronically dosed with Aroclors 1016, 1242, 1254, and 1260. Toxicologist 36, 88.

Botts, S., Jokinen, M. P., Isaacs, K. R., Meuten, D. J., and Tanaka, N. (1991). Proliferative lesions of the thyroid and parathyroid glands, E-3. Guides for Toxicologic Pathology, STP/ARP/AFIP. Washington, DC.

Bradlow, H. L., Sepkovic, D. W., Telang, N. T., and Osbome, M. P. (1995) Indole-3-carbinol-A novel approach to breast cancer prevention. Ann. NY Acad. Scl. 768, 180-200.

Capen, C. C. (1996). Hormonal imbalances and mechanisms of chemical injury of the thyroid gland. Endocrine System. Series II. Monographs on the Pathology of Laboratory Animals (Jones, T. C., et al., Eds.), pp. $217-$ 238. International Life Sciences Institute Senes, Springer-Verlag, New York.

Chen, L.-C., Berberian, I., Koch, B., Mercier, M., Azais-Braesco, V., Glauert, H. P., Chow, C. K., and Robertson, L. W. (1992). Polychlorinated and polybrominated biphenyl congeners and retinoid levels in rat tissues: Structure-activity relationships. Toxicol. Appl. Pharmacol. 114, 47-55.

Curran, P. G., and DeGroot, L. J. (1991). The effects of hepatic enzymeinducing drugs on thyroid hormones and the thyroid gland. Endocr. Rev. $12,135-150$.

Fish, K. M., Mayes, B. A., Brown, J. F., Jr., and Silkworth, J. B. (1997). Biochemical measurements on hepatic tissues from SD rats fed Aroclors 1016, 1242, 1254, and 1260. Toxicologist 36, 87.

Fishman, J., Osborne, M P , and Telang, N. T. (1995). The role of estrogen in mammary carcinogenesis. Ann. NY Acad. Sci. 768, 91-100.

Goodman, D. G., Maronpot, R. R., Newberne, P. M., Popp, J. A., and Squire, R. A. (1994). Proliferative and selected other lesions in the liver of rats, GI-5. Guides for Toxicologic Pathology. STP/ARP/AFIP. Washington, DC.

Hardisty, J. F., Mann, P. C., Brown, W. R., Elwell, M. R., Stromberg, P. C., Swenberg, J. A., and Ward, J. M. (1996). An Assessment of the Chronic Toxicity and Oncogenicity of Aroclor-1016, Aroclor-1242, Aroclor-1254, and Aroclor-1260 Administered in Diet to Rats: Pathology Peer Review and Pathology Working Group Review of Neoplastic Lesions in the Liver and Thyroid Gland Experimental Pathology Laboratories, Inc., Research Triangle Park, NC.

Haseman, J. K. (1984). Statistical issues in the desıgn, analysıs and interpretation of animal carcinogenicity studies. Environ. Health Perspect. 58, 385-392.

Ito, N., Nagasakı, H., Arai, M., Makiura, S., Sugihara, S., and Hırao, K. (1973). Histopathologic studies on liver tumorigenesis induced in mice by technical polychlorinated biphenyls and its promoting effect on liver tumors induced by benzene hexachloride. J. Natl. Cancer Inst. 51, 16371646.

Keenan, K. P., Soper, K. A., Smıth, P. F, Ballam, G. C., and Clark, R. L. (1995). Diet, overfeeding, and moderate dietary restriction in control Sprague-Dawley rats. I. Effects on spontaneous neoplasms. Toxicol Pathol. 23, 269-286.

Kimbrough, R. D., Squire, R. A., Lınder, R E., Strandberg, J. D., Montal, R. J., and Burse, V.W. (1975). Induction of liver tumors in Sherman strain female rats by polychlorinated biphenyl Aroclor 1260. J. Natl. Cancer Inst. 55, 1453-1459.

Kociba, R. J., Keyes, D. G., Berer, J. E., Carreon, R. M., Wade, C. E., Dittenber, D. A., Kalnins, R. P, Frauson, L. E., Park, C. N., Barnard, S. D., et al. (1978). Results of a two-year chronic toxicity and oncogenicity study of 2,3,7,8-tetrachlorodibenzo-p-dioxin in rats. Toxicol. Appl. Pharmacol. 46, 279-303.

Monsanto (1980). Polychlorinated Biphenyls (PCB's): A Report on Uses, Environmental and Health Effects and Disposal.

Moore, J. A., Hardisty, J. F., Banas, D. A , and Smith, M. A. (1994). A comparison of liver tumor diagnoses from seven PCB studies in rats. Regul. Toxicol. Pharmacol. 20, 362-370.

Nagasaki, H., Tomı, S., Mega, T., Marugamu, M., and Ito, N. (1972). Hepatocarcinogenicity of polychlorinated biphenyls in mice. GANN 63, 805.

National Cancer Institute (1978). Bioassay of Aroclor 1254 for possible carcinogenicity. CAS No. 27323-18-8. NCI Carcinogen. Tech. Rep. Ser. 38.

Norback, D. H., and Weltman, R. H. (1985). Polychlorinated biphenyl induction of hepatocellular carcinoma in the Sprague-Dawley rat. Environ. Health Perspect. 60, 97-105.

Preston, B. D., Van Miller, J. P., Moore, R. W., and Allen, J R. (1981) Promoting effects of polychlorinated biphenyls (Aroclor 1254) and polychlorinated dibenzofuran-free Aroclor 1254 on diethylnitrosamine-induced tumorigenesis in the rat. J. Natl. Cancer lnst. 66, 509-515.

Sauberlıch, H. E., and Hodges, R. E. (1997). Vitamın A deficiency and anemia. Nutr. Rev. 37, 38-40.

Schaeffer, E., Greim, H., and Goessner, W. (1984). Pathology of chronic polychlorinated biphenyl (PCB) feeding in rats. Toxicol. Appl. Pharmacol. 75, 278-288.

Silkworth, J. B , Mayes, B. A., Hamilton, S. B., and Brown, J. F., Jr (1997) Tissue levels and tumor responses of SD rats fed Aroclors 1016, 1242, 1254 , and 1260 suggest two processes critical to hepatotumorigenesis. Toxicologist 36, 158

U.S. Environmental Protection Agency (1988) Drinking Water Criteria Document for Polychlorinated Biphenyls (PCBs) EPA, PB89-192256.

U.S. Environmental Protection Agency (1996). PCBs: Cancer Dose-Response Assessment and Application to Environmental Mixtures. EPA, 600/P-96/001.

U.S. Environmental Protection Agency (1992). Health Effects Testung Guidelines: Oncogenicity. Code of Federal Regulations 40CFR798.3300.

U.S. Environmental Protection Agency (1992). Good Laboratory Practice Standards. Code of Federal Regulations. 40CFR792. 